\title{
A review of recent advances and future challenges in freshwater salinization
}

\author{
Miguel Cañedo-Argüelles*
}

Freshwater Ecology and Management (FEM) Research Group, Departament de Biologia Evolutiva, Ecologia i Ciències Ambientals, Institut de Recerca de l'Aigua (IdRA), Universitat de Barcelona (UB), Diagonal 643, 08028 Barcelona, Catalonia, Spain.

* Corresponding author: mcanedo.fem@gmail.com

Received: 19/04/18 Accepted: 27/02/019

\begin{abstract}
A review of recent advances and future challenges in freshwater salinization

In spite of being a worldwide phenomenon that can have important ecological, economic and social consequences, freshwater salinization (i.e. the increase in ion concentrations in freshwaters) has been poorly studied when compared with other environmental issues. However, it is receiving increasing attention, with significant scientific advances being made during the last two decades. Here I review the current knowledge on the topic and propose future research directions within the context of human welfare and global change. Freshwater salinization is caused by a wide range of human activities, with agriculture and resource extraction being the most widely documented. Different studies suggest that it could be affecting around 1/3 of freshwater bodies, and this number will very likely increase in the future due to climate and land use changes. The increase in the salinity of freshwaters is known to cause adverse effects on the fitness and survival of many aquatic organisms, however the osmoregulatory mechanisms underlying these effects are still poorly understood. Moreover, it has been proved that different ions can have different toxicities to aquatic organisms, but most of the research has focused exclusively on $\mathrm{Na}^{+}$and $\mathrm{Cl}^{-}$. Thus, more investigations on the potential effects of increasing concentrations of other specific ions (e.g. $\left.\mathrm{K}^{+}, \mathrm{SO}_{4}{ }^{2-}\right)$ are needed. The impact of salinization on freshwater biodiversity can alter ecosystem functioning, although only a few functions have been studied (e.g. leaf litter decomposition). Also, freshwater salinization can affect the delivery of ecosystem services and have direct economic (e.g. infrastructure corrosion) and social (e.g. human health) impacts that have rarely been assessed. The management of this urgent environmental issue needs to be improved through mitigation (e.g. backfilling of mine tailings), remediation (e.g. enhanced wastewater treatment), prevention (e.g. using alternative deicers for roads) and monitoring (e.g. estimating salt loads to freshwater ecosystems) actions.
\end{abstract}

Key words: salinity, pollution, sub-lethal effects, resource extraction, agriculture, climate change, ecosystem functioning, wastewater treatment, human health

\section{RESUMEN}

\section{Revisión de los avances recientes y los desafios futuros en la salinización de los ecosistemas de agua dulce}

A pesar de ser un fenómeno mundial que puede tener importantes consecuencias ecológicas, económicas y sociales, la salinización de los ecosistemas acuáticos (es decir, el aumento de las concentraciones de iones en sus aguas) ha sido poco estudiada en comparación con otros problemas ambientales. Sin embargo, está recibiendo una atención cada vez mayor, con importantes avances científicos realizados durante las últimas dos décadas. Aquí reviso el conocimiento actual sobre el tema y propongo futuras direcciones de investigación en el contexto del bienestar humano y el cambio global. La salinización de los ecosistemas acuáticos es causada por una amplia gama de actividades humanas, siendo la agricultura y la extracción de recursos las más ampliamente documentadas. Diferentes estudios sugieren que podría estar afectando alrededor de 1/3 de los cuerpos de agua dulce, y este número probablemente aumentará en el futuro debido a los cambios en el clima y los usos del suelo. Se sabe que el aumento en la salinidad de las aguas dulces causa efectos adversos en la condición física y la supervivencia de muchos organismos acuáticos, sin embargo, los mecanismos osmorreguladores que subyacen a estos efectos aún no se conocen bien. 


\begin{abstract}
Además, se ha demostrado que diferentes iones pueden tener diferentes toxicidades para los organismos acuáticos, pero la mayoría de las investigaciones se han centrado exclusivamente en los iones $\mathrm{Na}^{+}$y $\mathrm{Cl}^{-}$. Por lo tanto, se necesitan más investigaciones sobre los efectos potenciales de otros iones (por ejemplo, $\mathrm{K}^{+}, \mathrm{SO}_{4}{ }^{2-}$ ). El impacto de la salinización en la biodiversidad de agua dulce puede alterar el funcionamiento de los ecosistemas acuáticos, aunque solo se han estudiado algunas funciones (por ejemplo, la descomposición de la hojarasca), y podría afectar a la provisión de servicios ecosistémicos. Finalmente, la salinización de agua dulce también puede tener impactos económicos directos (p. ej. corrosión de la infraestructura) y sociales (p. ej. problemas de salud humana) que rara vez se han evaluado. La gestión de este urgente problema ambiental debe de mejorarse a través de acciones de mitigación (p. ej. retorno de los residuos mineros a los huecos de las explotaciones mineras), remediación (p. ej. tratamiento mejorado de aguas residuales), prevención ( $p$. ej. uso de descongeladores alternativos para carreteras) y monitoreo (p. ej. estimación de las aportaciones de sal a los ecosistemas de agua dulce).
\end{abstract}

Palabras clave: salinidad, contaminación, efectos sub-letales, extracción de recursos, agricultura, cambio climático, funciones ecosistémicas, tratamiento de aguas residuales, salud humana

\section{INTRODUCTION}

Freshwater salinization can be defined as an increase in the ion concentration of freshwater ecosystems. However, it should be noted that salinization not only changes the total concentration of total dissolved ions, but it usually changes ion ratios as well. Marine and freshwaters greatly differ in the concentration and proportion of ions, with the former being dominated by $\mathrm{Na}^{+}$and $\mathrm{Cl}^{-}$ and the latter by $\mathrm{Ca}^{2+}$ and $\mathrm{HCO}_{3}{ }^{-}$(Margalef, 1986). This is important because aquatic organisms have evolved under relatively constant ion concentrations and ratios. As Ranking \& Davenport (1981) stated: "The body fluids of living organisms are dilute salt solutions reflecting the origin of life in the sea". Thus, it is not surprising that dissolved salts (i.e. ions) concentrations in the water are one of the main factors controlling life on Earth (Bradley, 2008) and probably in other planets (Marion et al., 2003). Aquatic animals need to maintain a balance between the osmotic concentrations of their internal media (i.e. cells and body fluids) and the media in which they live (i.e. water) (Rankin \& Davenport, 1981; Larsen et al., 2014). Most aquatic organisms have the ability to control internal ion concentrations (i.e. osmoregulation) to some limit. Pass this limit osmoregulation breaks down, and they start to osmoconform (Williams \& Feltmate, 1992). Eventually, cells are damaged and die, leading to stress and mortality of the individuals. Consequently, aquatic communities are strongly shaped by the salinity of their surrounding water. For example, the species richness of brackishwater environments is largely constrained by salinity fluctuations (Remane \& Schlieper, 1971; Attrill \& Rundle, 2002), which have important evolutionary implications for the physiology of salt and water balance (Larsen et al., 2014). Also, background salinity (i.e. not modified by human action) is known to limit species richness in streams (Egglishaw \& Mackay, 1967; Minshall \& Kuehne, 1969). This is especially evident in arid streams, which can comprise endemic fauna with salinity adaptations (Sánchez-Fernández et al., 2008; Millán et al., 2011). For example, Arribas et al. (2013) found 4 cryptic species within the Enochrus falcarius species complex that could have emerged from allopatric speciation caused by the isolation of saline habitats (i.e. surrounded by a matrix of freshwater habitats).

Freshwater salinization is caused by a wide variety of activities (Fig. 1). The most documented are: agriculture and pasture (Allison et al., 1990; Williams, 2001a; Halse et al., 2003), resource extraction (Pond et al., 2008; Cañedo-Argüelles et al., 2012; Warner et al., 2013) and the use of salts as deicing agents for roads (Kaushal et al., 2005; Corsi et al., 2010). Urban and industrial wastewaters can also contribute to increase ion concentrations in receiving water bodies, but they have been suggested to be less important (Meybeck, 2003; Berger et al., 2017).

The increase of salts in freshwater ecosystems is known to greatly reduce aquatic biodiversity (Cañedo-Argüelles et al., 2013), being among the top causes of biological degradation in rivers and streams (Vander Laan et al., 2013; De CastroCatalà et al., 2015) and one of the stressors with 


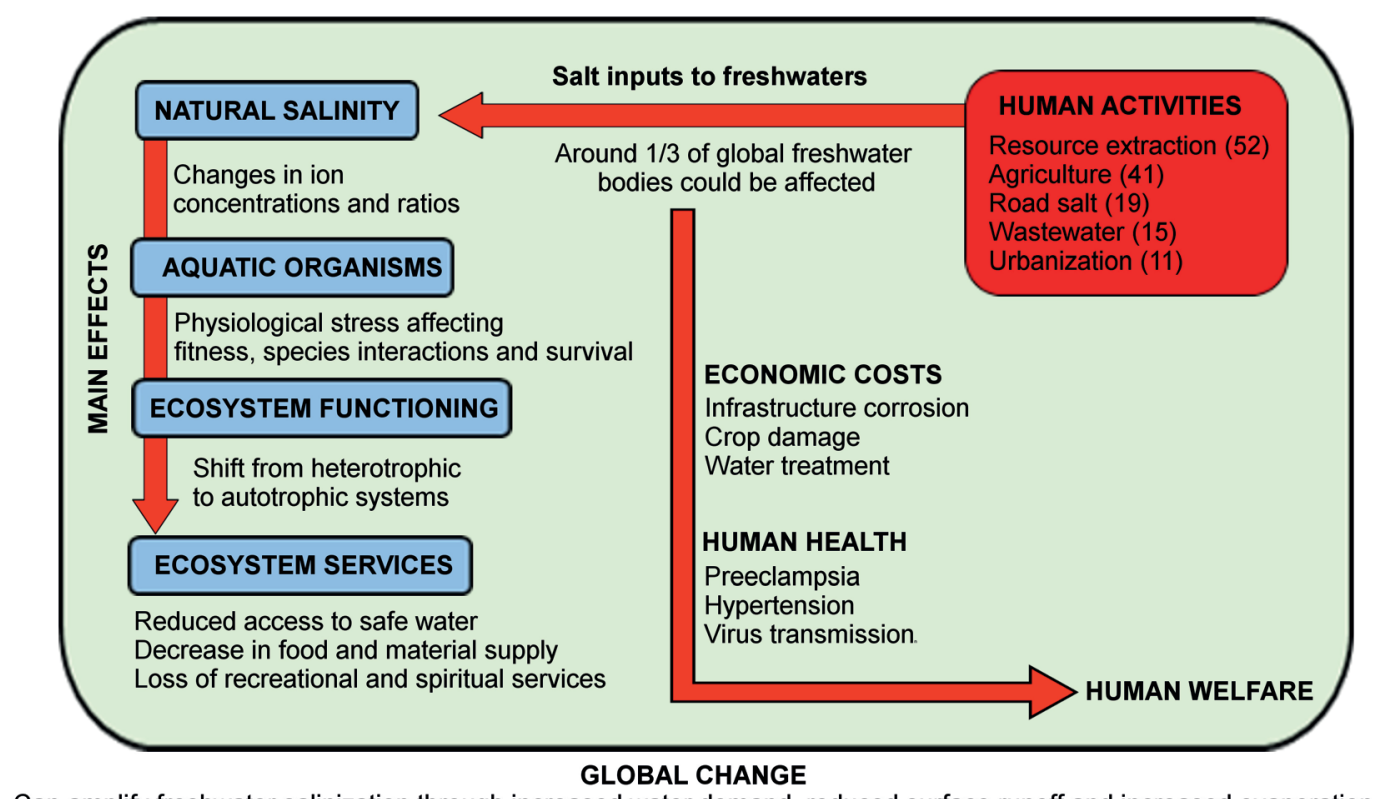

Figure 1. Schematic diagram of the main topics covered in this paper. Human activities modify the ion concentrations and ratios of freshwater ecosystems through point source and diffuse salt pollution (i.e. freshwater salinization). This has an impact on aquatic organisms through physiological stress that leads to changes in ecosystem functioning and the delivery of ecosystems services. Additionally, freshwater salinization have direct economic costs and effects on human health that, combined with the impacts on ecosystems, affect human welfare. The impacts of freshwater salinization on ecosystems and human welfare will very likely be amplified in the future due to global change, since the salt dilution capacity of freshwater bodies will be reduced. Next to each human activity, in brackets, I show the number of cited papers referred to each of them. Diagrama esquemático de los principales temas tratados en este artículo. Las actividades humanas modifican las concentraciones y proporciones de iones de los ecosistemas de agua dulce (fenómeno denominado salinización de los ecosistemas acuáticos). Esto tiene un impacto en los organismos acuáticos a través del estrés fisiológico que conduce a cambios en el funcionamiento del ecosistema y la prestación de servicios ecosistémicos. Además, la salinización de los ecosistemas acuáticos tiene costos económicos y efectos directos en la salud humana que, combinados con los impactos en los ecosistemas, afectan el bienestar humano. Es muy probable que los impactos de la salinización en los ecosistemas y el bienestar humano se amplifiquen en el futuro debido al cambio global, ya que la capacidad de dilución de sal de los cuerpos de agua dulce se reducirá. Junto a cada actividad humana, entre paréntesis, muestro el número de documentos citados referidos a cada una de ellas.

the strongest potential impact on aquatic organisms (Velasco et al., 2019). Biodiversity reduction occurs at both taxonomic and functional levels (Piscart et al., 2006; Szöcs et al., 2014; Suárez et al., 2017), and it decreases more rapidly after a certain threshold is reached. According to field studies, the salinity threshold at which most freshwater species are extirpated could be around 4-10 g/L (Williams et al., 1990; Pinder et al., 2005), but it can vary widely among taxa (Kefford et al., 2012). Salt pollution had been already acknowledged as a water quality problem since the 1920s (Meybeck \& Helmer, 1989). Also, Dr. Robert A. Berner showed in 1971 that roughly one-third of the sulphate carried by rivers was derived from the activities of man. However, freshwater salinization was largely neglected by most water resource managers, conservationists and limnologists for decades (Williams, 2001b). Several papers with a wide focus on the topic have been published during the last 18 years (e.g. Williams 2001a; Herbert et al., 2015; Cañedo-Argüelles et al., 2016; Dugan et al., 2017; Kaushal et al., 2018; Cañedo-Argüelles et al., 2019), but it is still receiving much less attention than other environmental issues (Fig. 2). In my opinion, this could be related with the common belief among scientists that this is a local issue occurring almost exclusively in arid regions. Additionally, the fact that salts occur naturally in freshwaters 
has probably prevented scientist and managers from considering salts as pollutants (Gorostiza \& Sauri, 2019). Here I review the latest advances in freshwater salinization research, paying special attention to river ecosystems. The aim of this paper is to promote future investigations on the topic by identifying current knowledge gaps and management needs.

\section{THE SPATIAL EXTENT OF FRESHWATER SALINIZATION}

How many freshwater ecosystems of the world are salinized? Are there freshwater salinization hotspots? Given the available information, it is very difficult to answer these questions precisely. The global spatial extent of freshwater salinization remains unknown but available data suggests that it is affecting a large proportion of freshwater ecosystems. For example, Kausahl et al. (2018) estimated that salinization had impacted $37 \%$ of the drainage area of the contiguous USA, observing statistically increasing trends at $39 \%$ of sites for specific conductance, $34 \%$ of sites for sodium, $29 \%$ for calcium, $33 \%$ for magnesium, and $36 \%$ for potassium concentrations. Similarly, Estévez et al. (2019) showed that around $27 \%$ of the streams in Spain were salinized. Finally, Le et al. (2019) found statistically increasing trends in electrical conductivity (EC) for around $80 \%$ of the streams in Germany.

Among the different causes of freshwater salinization, agriculture seems to be the most important (Estévez et al., 2019). In 2001 Williams (2001a) reported that over $10 \%$ of all irrigated land was already damaged and around $25 \%$ of the world water bodies could be salinized by agriculture. Other estimates are considerably higher and indicate that around $20-50 \%$ of all irrigated lands may be salt-affected (Pitman \& Läuchli, 2002). Since agricultural land is rapidly expanding (Foley et al., 2005), these numbers will likely increase in the future. Resource extraction is another major cause of freshwater salinization through both the disposal of produced waters and the weathering of exposed rocks. For example, shale gas extraction can produce waters up to 7 times more saline than seawater (Vengosh et al., 2014). This salinization source will also become more important in the future (Ferrar et al., 2013). In the USA shale gas extraction is expected to increase threefold and will account for nearly half of all natural gas produced by 2035 (Entrekin et al., 2011). This might lead to huge volumes of salinized water entering freshwaters through shale gas wastewater disposal, spills and application to roads (Olmstead et al., 2013; Patterson et al., 2017; Tasker et al., 2018). Rozell $\&$ Reaven (2012) projected that if only $10 \%$ of the Marcellus shale region was developed, this would result in a volume of contaminated water equalling a few thousand Olympic-sized swimming pools. Potash mining is another major source of salts in rivers and streams. For example, due to the potash mines in Alsace, the estimated chloride load increased in the Rhine River from less than $50 \mathrm{~kg} / \mathrm{s}$ to more than $300 \mathrm{~kg} / \mathrm{s}$ in the 1960's (Meybeck \& Helmer, 1989). In Germany, the River Werra registered peak $\mathrm{Cl}^{-}$concentrations of $30 \mathrm{~g} / \mathrm{L}$ when flowing near the salt mines

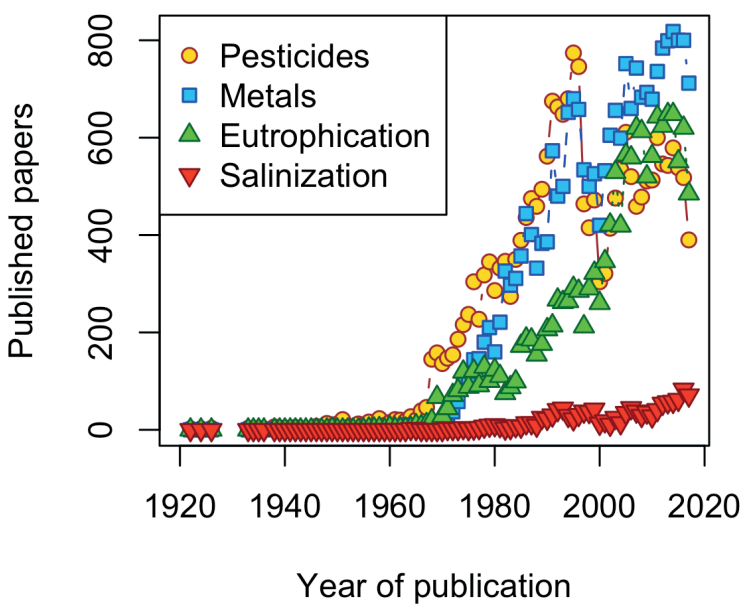

Figure 2. Number of papers published by year (not cumulative) on pesticide and metal pollution, eutrophication and salinization of freshwaters. The data was retrieved from the Web of Science website on the 26th of Februarys of 2018 after searching for the terms "freshwater pesticide", "freshwater metal", "freshwater eutrophication" and "freshwater salinization", respectively. Número de artículos publicados por año (no acumulativos) sobre contaminación de plaguicidas y metales, eutrofización y salinización de ecosistemas acuáticos. Los datos se obtuvieron de la página web Web of Science el 26 de febrero de 2018 después de buscar los términos "freshwater pesticide", "freshwater metal", "freshwater eutrophication" and "freshwater salinization", respectivamente. 
(Coring \& Bäthe, 2011). Road salt is emerging as another important source of salts (mainly $\mathrm{NaCl}$ ) into freshwaters in the cold regions of the world (Lofgren, 2001; Ruth, 2003; Kaushal et al., 2005) and it is tightly linked to urbanization (Novotny et al., 2008; Kaushal et al., 2018). Due to the application of $\mathrm{NaCl}$ as a deicing agent in roads $\mathrm{Cl}^{-}$ concentrations exceeded U.S. Environmental Protection Agency (USEPA) acute $(860 \mathrm{mg} / \mathrm{L})$ and chronic $(230 \mathrm{mg} / \mathrm{L})$ water-quality criteria at 55 and $100 \%$ of monitored sites in 11 watersheds of Milwaukee (USA), respectively (Corsi et al., 2010). Road salt application might also increase in the future due to urban expansion. In the US, it has increased from 0.20 to 24.5 million metric tons per year in seven decades (Coldsnow et al., 2017a). Although there is not much information about it, industrial effluents are likely to further contribute to freshwater salinization (Berner, 1971; Piscart et al., 2005). For example, in the US the chemical industry accounted for about $37 \%$ of total salt sales in 2017 (Ober, 2018). Finally, chemical weathering of carbonate rich urban infrastructure can be a potential source of $\mathrm{Ca}^{2+}$, $\mathrm{Mg}^{2+}$ and other major ions to streams (Kaushal et al., 2014, 2015, 2017; Bird et al., 2018).

Arid lands with naturally saline groundwater are a good example of freshwater salinization hotspots and show how this issue is probably occurring more widely than it is being reported. Taking Australia as an example (Allison et al., 1990; Williams, 2001a), it has been proved that forest clearing for agriculture and pasture in these areas leads to freshwater salinization trough rising water tables (that are naturally saline) due to a reduction in the soil water retention capacity. However, naturally saline groundwaters are not restricted to Australia, they occur worldwide and are especially abundant in Asia (Van Weert et al., 2009). For example, the largest area with high groundwater salinity is found in West and Central Asia (Van Weert et al., 2009) and $23 \%$ of the $30000 \mathrm{~km}^{3}$ of groundwater stored in the Indo-Gangetic Basin (IGB) alluvial aquifer has a salinity greater than $1 \mathrm{~g} / \mathrm{L}$ (MacDonald et al., 2016). Thus, it is reasonable to assume that, similarly to Australia, freshwater salinization is widely occurring in agricultural areas of Asia, although only a few cases have been reported (e.g. the Aral Sea region: Létolle \& Chesterikoff, 1999; Micklin, 2007; Aladin et al., 2009). Additionally, salinization of Asian rivers and streams have been associated with urban development (Bhatt \& McDowell, 2007) and chemical, paper and textile industries (Lokhande et al., 2011; Nirgude et al., 2013). Examples of freshwater salinization can also be found in other regions of the world. In South America, very high salt loads into the Amazon River have been reported due to oil extraction (Moquet et al., 2014). Also, increases in the salinity of freshwaters have been associated with salt factories (González Achem et al., 2015) and drainage canals (Bazzuri et al., 2018) in Argentina and salt extraction (Akomolafe \& Onwusiri, 2017), agriculture (Scherman et al., 2003) and industry (Dikio, 2010) in Africa.

Increased water demand (Vörösmarty et al., 2000) will exacerbate freshwater salinization, since it leads to reduced salt dilution capacity of water bodies. For example, very high concentration of salts toxic to aquatic fauna have been found in saline lakes due to lowering water levels (Aladin et al., 2009; Herbst et al., 2013). Also, a combination of sea-level rise and seawater intrusion caused by groundwater over-exploitation for agriculture is leading to the salinization of coastal freshwater ecosystems (Mirza, 1998; Craft et al., 2009; Mahmuduzzaman et al., 2014; Herbert et al., 2015; Pereira et al., 2019). Blankespoor et al. (2012) predicted that freshwater wetlands would be lost at an average rate of $64 \%$ to submergence and conversion to saline systems following a 1-m rise in sea level, with the highest regional loss rates in the Middle East and North Africa (100 $\%)$, Latin America and the Caribbean (74\%), Sub-Saharan Africa (72.5\%), and East Asia and the Pacific (62.2 \%). Additionally, climate change-induced extreme precipitation (IPCC, 2013) might increase the frequency of river embankment overtopping, thereby flooding surrounding water bodies with saline river water (Karim \& Mimura, 2008). Overall, it is clear that freshwater salinization will expand and increase in the future. Olson (2019) predicted that by 2100 $12 \%$ of the streams in the USA will have an EC greater than $2 \mathrm{mS} / \mathrm{cm}$ and the number of streams unusable for irrigation will double due to the 
combined effect of land use and climate change. Also, Le et al. (2019) predicted that EC will increase by $50 \%$ in $5-10 \%$ of the streams in Germany in the period from 2070 to 2100 .

\section{OSMOREGULATION AND ION TOXICITY}

We know that different ions are regulated by different, but functionally similar, transporters (Griffith, 2017) and that body size and phylogeny are probably important factors determining salt sensitivity through their effect on the ion uptake rates of aquatic organisms (Kefford et al., 2012; Poteat \& Buchwalter, 2014; Scheibener et al., 2016). However, there is still much uncertainty regarding basic osmoregulatory processes in freshwater fauna and how they relate to toxicity, especially for some ions (e.g. $\mathrm{SO}_{4}{ }^{2-}$ ) and taxa (e.g. aquatic insects, amphibians) (Hopkins \& Brodie, 2015; Scheibener et al., 2017). For example, it is not fully understood why some mayfly species experience significant mortalities at ECs lower than those of their haemolymph (Dowse et al., 2017; Kefford et al., 2019).

Although $\mathrm{NaCl}$ has received most of the scientific and public attention as a dominant form of salt pollution, other salts can greatly contribute to salinization (Kaushal et al., 2018). Cormier et al. (2013) found that $\mathrm{HCO}_{3}$ - and $\mathrm{SO}_{2}{ }^{4-}$ concentrations were greater than $\mathrm{Cl}^{-}$concentrations in most catchments of West Virginia (USA). Also, Moore et al. (2017) proved that concrete weathering can be an important source of $\mathrm{Ca}^{2+}$ and $\mathrm{SO}_{2}{ }^{4-}$. This is important because available studies show that not all ions are equally toxic to freshwater biodiversity. For example, Potapova and Charles (2003) found that some diatom species in USA streams were strongly affected by the proportions of individual cations and anions, and by the ratio of monovalent to divalent cations. Scheibener et al. (2016) found that the dominant anion could profoundly influence $\mathrm{Na}^{+}$uptake rate in the caddisfly Hydropsyche betteni. Kunz et al. (2013) reported different sensitivities of different aquatic invertebrates to reconstituted water with different ionic matrices. Clements and Kotalik (2016) found that $\mathrm{MgCl}_{2}$ had toxic effects to stoneflies and mayflies below the EPA chronic chloride quality standard. Among the different ions, $\mathrm{K}^{+}$ seems to be the most toxic to freshwater fauna (Mount et al., 1997, 2016; Griffith, 2017) and $\mathrm{SO}_{2}{ }^{4-}$ seems to be more toxic than $\mathrm{Cl}^{-}$(Soucek \& Dickinson, 2015; Clements \& Kotalik, 2016). On the contrary, water hardness (i.e. dissolved $\mathrm{CaCO}_{3}$ and $\mathrm{MgCO}_{3}$ ) can ameliorate the toxic effects of other ions (Soucek \& Kennedy, 2005; Soucek, 2007b; Van Dam et al., 2010; Elphick et al., 2011; Soucek et al., 2011), except $\mathrm{K}^{+}$(Mount et al., 2016; Soucek et al., 2018). Also, $\mathrm{K}^{+}$could ameliorate $\mathrm{SO}_{2} 4$ - toxicity in cladocerans, midges, mussels and fish (Wang et al., 2016). Overall, it is clear that the impact of salinization on freshwater ecosystems will need to be assessed within the context of multiple interacting ions (Bogart et al., 2019; Schulz \& Cañedo-Argüelles, 2019).

Ion toxicity could vary greatly among taxa. For example, Castillo et al. (2018) performed a meta-analysis of lethal salinity concentrations and found that microinvertebrates were more sensitive to salinity than vertebrates and macroinvertebrates. Hintz \& Relyea (2017) showed that $\mathrm{MgCl}_{2}$ did not affect rainbow trout growth significantly, whereas it had been shown to greatly affect amphibians (Hopkins et al., 2013). Also, in a review of the German literature on freshwater salinization, Schulz \& Cañedo-Argüelles (2019) reported the following salinity sensitivity of freshwater fauna (from more to less sensitive): fish $>$ macroinvertebrates $>$ phytoplankton $>$ macrophytes $>$ diatoms Overall, available data suggest that amphibians, fish and certain macroinvertebrates (e.g. some caddisflies and stoneflies) are among the most sensitive to salinity (Cañedo-Argüelles et al., 2013). However, the comparisons of salt toxicity across organisms are scarce. Moreover, it is still unclear whether the different response of organisms to salt toxicity results from total ionic concentration, the concentration of certain ions or the relative ratio of ions to each other (van Dam et al., 2014; Scheibener et al., 2017).

\section{INTERACTION WITH OTHER STRESSORS}

Freshwater ecosystems are affected by different point-source and diffuse pollution sources as well as hydrological and physical alterations, thus being subjected to multiple and interacting stressors (Meybeck, 2003; Walsh et al., 2005; Ormerod 
et al., 2010; Jackson et al., 2016). Given that salinization is caused by a wide variety of human activities, its potential interacting stressors are many and can interact in multiple ways (Velasco et al., 2019). Here I focus on those that have been most widely reported in the literature.

\section{Alkalization}

Increasing concentrations of dissolved salts with strong bases and carbonates, together with the displacement of base cations on soil exchange sites, can increase the $\mathrm{pH}$ of fresh water over time, linking salinization to alkalization (Kaushal et al., 2018). This is mainly associated with the weathering of carbonate lithology by acid rain, which is leading to increasing trends in alkalization (Kaushal et al., 2013). Alkalization can have a wide variety of effects on freshwater ecosystems, e.g. increasing dissolved organic carbon (Steele \& Aitkenhead-Peterson, 2013), contributing to ammonia toxicity (Erickson, 1985; Boyd et al., 2016) and stimulating nitrate production by microbial nitrification (Kaushal et al., 2014). Although alkalinity alters the toxicity of different ions (Mount et al., 2016), there is barely any information on the potential synergistic, antagonistic and additive effects of alkalization and salinization. Given that both stressors generally co-occur, this is an issue that deserves to be studied. Moreover, the interaction between alkalization and salinization could promote ocean acidification (Kaushal et al., 2018).

\section{Metals}

Salinity has been widely reported to ameliorate the toxicity of most metals (Cañedo-Argüelles et al., 2013). This is probably related with lower salinities leading to a greater bioavailability of toxic metal forms (Hall \& Anderson, 1995) and to a modification of osmoregulation leading to higher metal uptake (Grosell et al., 2007). Available studies suggest that different ions interact in different ways with metals (Boyd et al., 2016), affecting their toxicity (e.g. $\mathrm{Ca}^{2+}$ can be more effective than $\mathrm{Mg}^{2+}$ in ameliorating $\mathrm{Cu}^{2+}$ toxicity). However the mechanisms behind the interactions of metals with specific ions are still poorly understood and they can vary across taxa. For example, Scheibener et al. (2016) found that silver $(\mathrm{Ag})$ and copper $(\mathrm{Cu})$, known to be antagonistic to $\mathrm{Na}^{+}$uptake in other aquatic taxa, did not exhibit this effect in different caddisfly and mayfly species. Also, Poteat and Buchwalter (2014) showed that $\mathrm{Ca}^{2+}$ uptake did not appear to be compromised by $\mathrm{Cd}$ or $\mathrm{Zn}$ exposure in caddisfly and mayfly species, whereas shared uptake pathways between $\mathrm{Ca}^{2+}$ and the heavy metals $\mathrm{Cd}$ and $\mathrm{Zn}$ had been reported for fish, crustaceans and molluscs. Although salts can ameliorate metal toxicity, salinization can also promote metal pollution by displacing metals from ion exchange sites on soils and sediments and by increasing their bioavailability (Kaushal et al., 2013; Schuler and Relyea, 2018; Kaushal et al., 2019). Overall, more information is needed on the effect of salts on the accumulation of metals in freshwaters and their potential impact on ecosystem functioning and service provision (Schuler \& Relyea, 2018).

\section{Pesticides}

Given that pesticides often co-occur with increased ions concentrations in agricultural regions (Williams, 1987), pesticides and salinity can potentially interact to impact aquatic fauna. However, the few available studies show contradicting results. Song et al. (1997) exposed salt marsh mosquitoes to four insecticides (aldicarb, dimethoate, imidacloprid, and tebufenozide) and found less mortality under isosmotic conditions than under hyperosmotic conditions (probably due to the energetic costs associated with osmoregulation). Also, the toxicity of organophosphate pesticides has been reported to increase with increasing salinity (Hall \& Anderson, 1995). On the contrary, other studies found no interaction between both stressors (Schäfer et al., 2011, 2012; Szöcs et al., 2012), suggesting that their combined effects might be exclusively additive.

\section{Eutrophication}

Salts can mobilize organic nitrogen, ammonium, and phosphorus via ion exchange (e.g. by the reduction of $\mathrm{NH}_{4}+$ by $\mathrm{Na}^{+}$) and stimulate eutroph- 
ication (Duan et al., 2012; Duan \& Kaushal, 2015; Kaushal et al., 2013, 2017; Haq et al., 2018). This can promote the proliferation of cyanobacteria blooms, not only because the direct effects of salts on algae (Cañedo-Argüelles et al., 2017), but also because the reduction of salt sensitive cladocerans which feed on algae (Jeppesen et al., 2007, 2015; Brucet et al., 2010). Since salinity and nutrient pollution often originate from the same sources (Walsh et al., 2005), the contribution of salinity to eutrophication (e.g. through algal proliferation) deserves further attention.

\section{Drought}

Several studies suggest that salinity tolerance evolved during periods of aridification, probably as a by-product of adaptation to desiccation (Céspedes et al., 2013; Arribas et al., 2014; Pallarés et al., 2016; Villastrigo et al., 2018). Thus, the response of aquatic organisms to both stressors should be tightly linked. In a study of cross-tolerance to drought and salinity by aquatic beetles, Pallarés et al. (2017) found that salinity exposure enhanced desiccation resistance by activating water uptake mechanisms, whereas desiccation exposure produced water loss and haemolymph osmolality that decreased salinity tolerance. Concordantly, Suárez et al. (2017) found an antagonistic interaction between both stressors (i.e. the net effect of the two stressors was not as strong as the sum of their independent effects) on aquatic macroinvertebrates, probably because they were affecting the same set of species. However, synergistic interactions between drought and salinization could also be expected for salt sensitive species like certain mayflies, since reduced water flows and levels (i.e. in lotic and lentic ecosystems, respectively) might cause an increase in water temperature, thereby enhancing salt toxicity (Jackson \& Funk, 2019). Also, the negative effects of water stress on fungal biomass can be amplified by salt pollution (Gonçalves et al., 2019a). Due to a combination of water withdrawals for human consumption (Foley et al., 2005) and climate change (Gudmundsson et al., 2018), both stressors will very likely intensify in the future in arid regions of the world (Jones et al., 2018). This could have important consequences for the aquatic ecosystems, since they could be colonized and dominated by a few salinity and/or drought tolerant species (Kefford et al., 2016) and ecosystems functions such as organic matter decomposition could be modified (Gonçalves et al., 2019a).

\section{SUB-LETHAL EFFECTS AND TROPHIC INTERACTIONS}

Salinization causes a decline in freshwater biodiversity, with salinity tolerances varying across ions, species and regions (Kefford et al., 2012; Cañedo-Argüelles et al., 2013; Herbert, 2015; Castillo et al., 2018). However, beyond causing mortality, increased salt concentrations can have sub-lethal effects on freshwater organisms that have been less studied and that might modify ecosystem functioning through alterations in individual fitness and trophic interactions. Johnson et al. (2015), Herbst et al. (2013) and Hintz \& Relyea (2017) found that salinization reduced growth of the mayfly Neocloeon triangulifer, the damselfly Enallagma clausum and the rainbow trout, respectively. This was very likely related with an energetic demand imposed by ion transportation for maintaining homeostasis (Romano et al., 2017; Buchwalter et al., 2019). Also salinization can trigger behavioural responses such as increased drift of stream insects to reach more suitable habitats (Clements \& Kotalik, 2016; Beermann et al., 2018).

There are several potential impacts of sub-lethal responses to salinization on trophic interactions. Increased salinity can trigger trophic cascades by promoting algal growth through a reduction in the feeding efficiency of herbivorous invertebrates (Soucek, 2007a; c), thereby promoting eutrophication (Jeppesen et al., 2007; Hintz et al., 2017; Schuler et al., 2017; Schulz \& Cañedo-Argüelles, 2019). Additionally, freshwater salinization can affect species co-existence. For example, Stănescu et al. (2017) showed that increased salinity could benefit the toad Pelobates syriacus over the sympatric and endangered P. fuscus, and Bray et al. (2019) found that the interaction between salt tolerant and sensitive communities could significantly affect the response of some invertebrate species to 
increased salinity in a mesocosm experiment. Concordantly, Arribas et al. (2019) argued that the dominance of certain species in saline habitats (i.e. saline species) could be more related with avoiding competition or predation than with physiological adaptations. The modification of species interactions by salinization should be also analysed from a meta-community perspective, since salinized freshwater bodies could be poor in species due to a limitation in the sources of salt tolerant organisms (i.e. naturally saline sites) nearby (Gutiérrez-Cánovas, et al., 2019). Finally, parasitism is another interaction that deserves to be studied within the frame of freshwater salinization. Buss and Hua (2018) found that $\mathrm{NaCl}$ increased tadpole susceptibility to parasites (i.e. trematodes), although this was dependent on the presence of tadpole predators (i.e. damselflies). Overall, salinized freshwater ecosystems could experience a reduction in food chain length due to constrained diversity of consumers and trophic resources in local food webs (East et al., 2017).

The response of organisms to salinization might depend on the background salinity at which their populations have evolved (Kefford et al., 2016). For example, the microcrustacean Daphnia pulex is known to rapidly evolve salt tolerance (Coldsnow et al., 2017a), which is transferred to sub-sequent generations through methylation (Jeremias et al., 2018). Also, intra-specific differences in salt sensitivity were found by Sala et al. (2016), who showed that individuals of the net-spinning caddisfly Hydropsyche exocelleta from low salinity streams built a lower number and less symmetric nets than a population coming from a salt-polluted stream. Salinity adaptation could have associated trade-offs modifying the organism performance. Coldsnow et al. (2017b) showed that increased salt exposure ablated the circadian clock of $D$. pulex, potentially affecting key behaviours like diel vertical migration. Adaptations to salinization could also play an important role in maintaining ecosystem stability, e.g. by mitigating trophic cascades (Hintz et al., 2019). However, salinity adaptations need further exploration, since some studies have found no evidence of enhanced salinity resistance after multigenerational exposure to increased salt concentrations (Loureiro et al., 2015; Venancio et al., 2019).

\section{EFFECTS ON ECOSYSTEM FUNCTIONING AND HUMAN WELFARE}

Freshwater salinization can have important impacts on ecosystem functioning. For example, in wetlands salinization can alter biochemical cycles, leading to eutrophication and reduced carbon storage (Herbert et al., 2015). In lakes, it can enhance water stratification, promoting phosphorous release from the sediment through the creation of anoxic conditions (Koretsky et al., 2012). In rivers and streams changes in water salinity can significantly alter riparian-stream connections through different pathways (e.g. soil and stream decomposers and plant salt uptake) (Entrekin et al., 2019). For example, salinization has been shown to diminish organic matter inputs and processing due to the reduction of riparian vegetation cover (Ladrera et al., 2017) and leaf litter breakdown by invertebrates (Schäfer et al., 2012; Cañedo-Argüelles et al., 2014), respectively. The effect of salinity on microbial decomposition is less clear. On one hand, some studies have reported that microorganism-mediated leaf litter breakdown could be most efficient at intermediate salinities (Cañedo-Argüelles et al., 2014; Sauer et al., 2016). On the other hand, Canhoto et al. (2017) showed that trade-offs between growth and sporulation can maintain fungal growth and decomposition at high levels along a wide $\mathrm{NaCl}$ gradient (0-16 g/L) and Gonçalves et al. (2019b) found no effect of salinization on fungal sporulation in strains coming from sites with different background salinities ( 0.01 vs. $6 \mathrm{~g} / \mathrm{L})$. Overall, based on information coming from arid streams (Millán et al., 2011; Berger et al., 2019), salinized streams are likely to act as net carbon exporters due to a decrease in allochthonous organic matter inputs and decomposition and an increase in algal production and eutrophication.

All the impacts of salinization on biodiversity and ecosystem functioning might affect the services that freshwater ecosystems provide (Berger et al., 2019). For example, the combined effects of salinization and drought led to the 


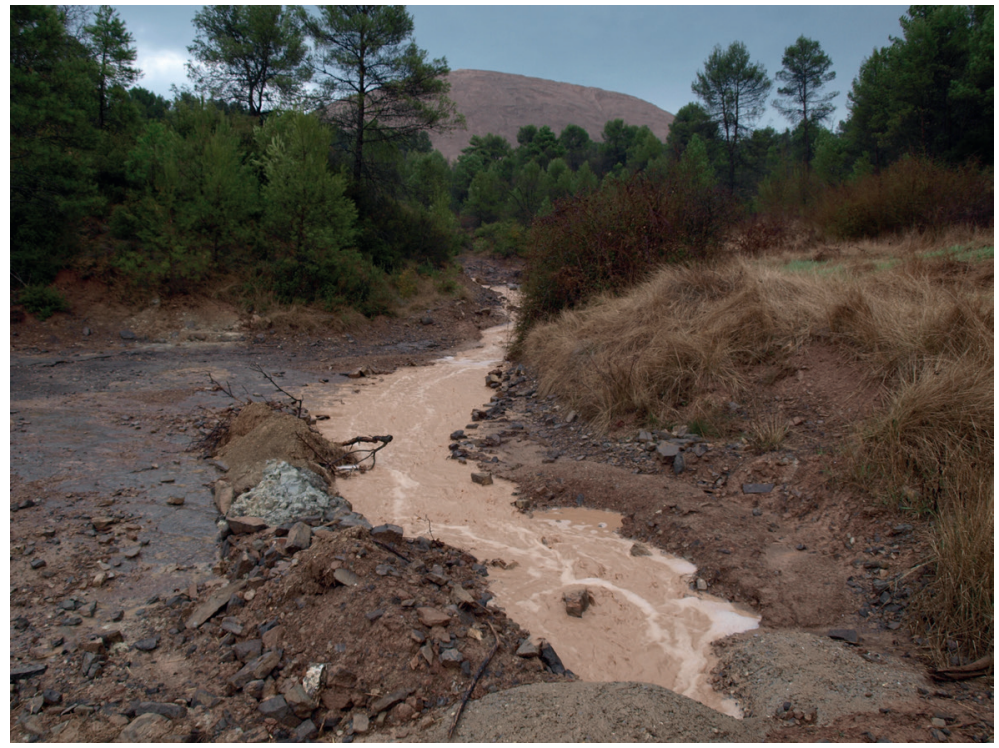

Figure 3. Impacted stream (Torrent de Soldevilla, Catalonia, Spain) by potash mining (picture by Ruben Ladrera, Universidad de La Rioja). Riparian vegetation is absent from the margins of the stream. The mine tailing (mainly composed by $\mathrm{NaCl}$ ) can be seen in the back of the picture. Arroyo impactado (Torrent de Soldevilla, Cataluña, España) por la minería de potasa (foto de Rubén Ladrera, Universidad de La Rioja). La vegetación ribereña está ausente de los márgenes del arroyo. El relave de la mina (compuesto principalmente por $\mathrm{NaCl}$ ) se puede ver en la parte posterior de la imagen.

collapse of fish populations in the Aral Sea, which were the main source of food and jobs for local residents (Micklin, 2007). Also, recreation and aesthetic values of freshwater ecosystems can be seriously compromised by salinization, due to a decline in habitat quality and biodiversity (Fig. 3). Finally, linked with ecosystem services, there are important economic and social costs associated with salt pollution of freshwaters (Cañedo-Argüelles et al., 2016; Schuler et al., 2019; Schulz \& Cañedo-Argüelles, 2019). Saline waters corrode infrastructure (Wilson, 2004; Moore et al., 2017) and increase water treatment costs (Honey-Roses \& Schneider, 2012). Moreover, when salinity increases the water can become useless for agriculture, domestic consumption and many industrial uses (Williams, 2001b; Kaushal, 2016, Schuler et al., 2019). Salinized water not only can become unpalatable and damage crops, it can also pose important risks to human health. In Bangladesh seawater intrusion in the coast is leading to health problems (e.g. preeclampsia, hypertension) and forced migrations of millions of people
(Karim \& Mimura, 2008; Khan et al., 2011, 2014; Vineis et al., 2011; Mahmuduzzaman et al., 2014; Dasgupta et al., 2015). Also, leaching metals from water infrastructure and sediments has contributed to increased lead concentrations in drinking water in the USA (Kaushal, 2016). In Spain, rivers affected by potash mining showed high concentrations of bromomethanes (Gorostiza \& Sauri, 2017), which have been related with cancer in humans (Min \& Min, 2016). Finally, the application of salts in roads to prevent icing can pose a risk to people with high blood pressure (Cooper et al., 2014). This is important because raised blood pressure is a major risk factor for coronary heart disease and the leading risk factor for stroke (Ezzati et al., 2002; He \& MacGregor, 2007; Scheelbeek et al., 2016). Besides risks associated with drinking water quality, freshwater salinization can affect human health through wind-borne dust (i.e. respiratory problems), virus transmission (e.g. promoting mosquito populations) and mental illness induced by environmental degradation (Jardine et al., 2007). 


\section{MANAGEMENT STRATEGIES}

Water managers and policy-makers have rarely been urged by society to manage freshwater salinization (Cañedo-Argüelles et al., 2016), although there have been notable exceptions (Gorostiza, 2014; Gorostiza \& Sauri, 2017). Thus, it is not surprising that cost-effective freshwater salinization prevention, remediation and mitigation strategies are generally lacking. The priority option to combat freshwater salinization should be to reduce salt loads at their origin. In the case of mining, wastes should be used to refill the excavated areas (i.e. backfilling) (Rauche et al., 2001; Benzaazoua et al., 2008) and vegetation should be planted to stabilize the soil and recover the natural landscape (i.e. phytostabilization) (Mendez \& Maier, 2008; Fellet et al., 2011). Brine collectors aimed at disposing mining waste waters and runoff into the sea (Martín-Alonso, 1994) do not seem to be a suitable long-term management option, since they can lead to saline water leaks (Gorostiza, 2014) and they can affect coastal ecosystems (Schulz \& Cañedo-Argüelles, 2019). In the case of shale gas extraction, produced waters can be injected deep underground. However, most operators prefer to recycle and then send waste waters to approved industrial wastewater treatment facilities because it is less costly (Rozell \& Reaven, 2012). Moreover, in some regions the availability of disposal wells might be limited (Ferrar et al., 2013; Vidic et al., 2013). In the case of regions with saline groundwaters, the salinization caused by land clearing can be ameliorated by lowering groundwater tables through water pumping (Williams, 2001b) and the plantation of salt tolerant trees in areas where groundwater is accessible to their roots (Queensland Government, 2011). Agricultural practices should also be improved to use the amount of water that the crops require, preventing salts from accumulating in the soils and groundwater tables to rise (Gardner \& Young, 1988; Pereira et al., 2007; URS, 2014). Finally, salt applications in roads should be improved by selecting salts according to temperature/melting point and improving calibration/salt delivery techniques and the design of stormwater retention ponds (Kaushal, 2016; Snodgrass et al., 2017). Additionally, alternative salts should be tested, although they tend to be more costly than $\mathrm{NaCl}$ (Jackson \& Jobbágy, 2005). Finally, deicing technologies that ensure safe driving conditions while minimizing road salt application should be developed and implemented (Schuler et al., 2019).

Another option for managing freshwater salinization is to improve wastewater treatment. Overall, wastewater treatment plants are not equipped to reduce dissolved ions (Entrekin et al., 2011; Ferrar et al., 2013), although multiple technologies (e.g. chemical precipitation, membrane technology, biological treatment) are available to do it (Shaffer et al., 2013; Pinto et al., 2016; Gibb et al., 2017; Runtti et al., 2018). This is mainly related with the high economic costs for the implementation and maintenance of these technologies (Karagiannis \& Soldatos, 2008; Honey-Roses \& Schneider, 2012). However, some promising advances are being made to reduce costs by using renewable energies (Mohamed \& Papadakis, 2004; Nafey et al., 2010) or biological treatments (Abou-Elela et al., 2010; Smyntek et al., 2017). Further technological developments coupled with rigorous cost-benefit analyses (including economic, environmental and social costs) are needed before remediation strategies can be widely implemented (Cañedo-Argüelles et al., 2016; Wang et al., 2018; Schuler et al., 2019). Additionally, salt loads to freshwater ecosystems should be estimated to guide pollution mitigation and restoration efforts (Zuidema et al., 2018; Schuler et al., 2019). Complementarily, hyperspectral remote sensing could be used to identify heavily salinized areas (Pfitzner et al., 2018). Finally, environmental flows should be established so the salt dilution capacity of rivers can be secured. For example, in the Murray Darling catchment (Australia) caps were placed on water diversions for consumptive uses and resulted in a recovery of aquatic biodiversity due to a reduction in salt concentrations (Paul et al., 2018).

Finally, developing specific freshwater salinization monitoring programs is urgently needed (Schuler et al., 2019). The concentration of dissolved ions in freshwaters can experience great intra and inter-annual variations due to changes in surface runoff (i.e. affecting the dilution capacity of continental waters and the diffuse salt inputs), evaporation and point-source 
discharges. Thus, it is very important to properly establish the monitoring periodicity of dissolved ions according to these fluctuations (Cañedo-Argüelles et al., 2012; Timpano et al., 2018). Since salinization can have multiple causes, stakeholders often deny responsibility (Gorostiza \& Sauri, 2019). Thus, monitoring programs should include chemical fingerprinting (e.g. stable isotopes) to assess the contribution of the different human activities along the catchment to freshwater salinization (Otero \& Soler, 2002; Osman et al., 2017). Also, current biological indices do not seem to adequately respond to salt pollution (Cañedo-Argüelles et al., 2012, 2017), thereby specific indices need to be developed (Schäfer $e t$ al., 2011; Vander Laan et al., 2013; Schulz, 2016; Halle et al., 2017; Timpano et al., 2018; Schulz \& Cañedo-Argüelles, 2019). These indices should rely in the definition of reference conditions according to natural ion concentrations, which can vary widely depending on the catchment geology (Hawkins et al., 2010; Griffith, 2014). Improved monitoring should be complemented with legally enforced standards for salinity and specific ion concentrations (both independently and in combinations) based on biodiversity and ecosystem protection (Cañedo-Argüelles et al., 2016; Wang et al., 2016; Cochero et al., 2017; Bogart et al., 2019; Schuler et al., 2019).

\section{OTHER FUTURE RESEARCH NEEDS}

There are other topics that have been poorly investigated and deserve further attention. For example, there are potential sources of freshwater salinization that remain uninvestigated, such as abandoned metal mines (Mighanetara et al., 2009), wildfires (Mast, 2013) and desalination brines (Kupsco et al., 2017). Additionally, the dilution of naturally saline streams by freshwaters (e.g. coming from agricultural runoff) should be considered, since it threats the unique biodiversity that these ecosystems harbour (Velasco et al., 2006; Sánchez-Fernández et al., 2008; Millán et al., 2011; Gutiérrez-Cánovas et al., 2019). Overall, research should not only focus on the effects of the modification on the concentration of certain ions, but also on the modification of ion ratios. Also, future studies should assess the rate and duration of salt pollution because they can determine the response of freshwater organisms through resistance and resilience mechanisms (Hogan et al., 2012; Cañedo-Argüelles et al., 2014; Cooper et al., 2014). Finally, freshwater salinization will very likely exacerbate in the future within the context of global change (Le et al., 2019; Olson 2019). Thus, we need robust predictions of how the concentration of dissolved ions in freshwaters will change around the world as a result of increased agriculture (Foley et al., 2005) and resource extraction (Krausmann et al., 2009; Entrekin et al., 2011), sea-level rise (IPCC, 2013; Mahmuduzzaman et $a l ., 2014)$ and reduced dilution capacity associated with lower river discharges (Dai et al., 2009; Döll \& Schmied, 2012) and lake levels (Jeppesen et al., 2015). These predictions should be coupled with other global scale phenomena that can be influenced by freshwater salinization, such as ocean acidification (Doney, 2010; Gypens et al., 2011; Kaushal et al., 2018).

\section{ACKNOWLEDGEMENTS}

I was supported by the MECODISPER project (CTM2017-89295-P) funded by the Spanish "Ministerio de Ciencia, Innovación y Universidades-Agencia Estatal de Investigación" and cofunded by the ERDF (European Regional Development Fund). I would like to thank the FEHM (Freshwater Ecology Hydrology and Management) research group, especially Dr. Narcís Prat who aroused and guided my interest on freshwater salinization through stimulating scientific discussions and continuous support. Also, I would like to thank the two anonymous reviewers for their comments and corrections on the original manuscript.

\section{REFERENCES}

ABOU-ELELA, S. I., M. M. KAMEL \& M. E. FAWZY. 2010. Biological treatment of saline wastewater using a salt-tolerant microorganism. Desalination, 250 (1): 1-5.

AKOMOLAFE, G. F. \& K. C. ONWUSIRI. 2017. Assessment of Microalgae Diversity and Water Salinity of a Salt Mine, Nasarawa State, Nigeria. Journal of Environmental and 
Agricultural Sciences, 10: 78-83. ISSN: 2313-8629

ALADIN, N., I. PLOTNIKOV, P. MICKLIN \& T. BALLATORE. 2009. Aral Sea: Water level, salinity and long-term changes in biological communities of an endangered ecosystem-past, present and future. Natural Resources and Environmental Issues, 15(1).

ALLISON, G. B., P. G. COOK, S. R. BARNETT, G. R. WALKER, I. D. JOLLY \& M. W. HUGHES. 1990. Land clearance and river salinisation in the western Murray Basin, Australia. Journal of Hydrology, 119 (1-4): 1-20. DOI: 10.1016/0022-1694(90)90030-2

ARRIBAS, P., C. ANDÚJAR, D. SÁNCHEZFERNÁNDEZ, P. ABELLÁN \& A. MILLÁN. 2013. Integrative taxonomy and conservation of cryptic beetles in the Mediterranean region (Hydrophilidae). Zoologica Scripta, 42 (2): 182-200. DOI: $10.1111 /$ zsc. 12000

ARRIBAS, P., C. ANDÚJAR, P. ABELLÁN, J. VELASCO, A. MILLÁN \& I. RIBERA. 2014. Tempo and mode of the multiple origins of salinity tolerance in a water beetle lineage. Molecular Ecology, 23 (2): 360-373. DOI: 10.1111/mec.12605

ATTRILL, M. J. \& S. D. RUNDLE. 2002. Ecotone or ecocline: ecological boundaries in estuaries. Estuarine, Coastal and Shelf Science, 55: 929-936. DOI: 10.1006/ecss.2002.1036

BAZZURI, M. E., N. A. GABELLONE \& L. C. SOLARI. 2018. The effects of hydraulic works and wetlands function in the Salado-River basin (Buenos Aires, Argentina). Environmental Monitoring and Assessment, 190 (2): 99. DOI: $10.1007 / \mathrm{s} 10661-017-6448-7$

BEERMANN, A. J., V. ELBRECHT, S. KARNATZ, L. MA, C. D. MATTHAEI, J. J. PIGGOTT \& F. LEESE. 2018. Multiple-stressor effects on stream macroinvertebrate communities: A mesocosm experiment manipulating salinity, fine sediment and flow velocity. Science of the Total Environment, 610: 961-971. DOI: 10.1016/j.scitotenv.2017. 08.084

BENZAAZOUA, M., B. BUSSIÈRE, I. DEMERS, M. AUBERTIN, É. FRIED \& A. BLIER. 2008. Integrated mine tailings management by combining environmental desul- phurization and cemented paste backfill: Application to mine Doyon, Quebec, Canada. Minerals Engineering, 21 (4): 330-340. DOI: 10.1016/j.mineng.2007.11.012

BERGER, E., P. HAASE, M. KUEMMERLEN, M. LEPS, R. B. SCHÄFER \& A. SUNDERMANN. 2017. Water quality variables and pollution sources shaping stream macroinvertebrate communities. Science of the Total Environment, 587: 1-10. DOI: 10.1016/j.scitotenv. 2017.02.031

BERGER, E., O. FRÖR \& R. B. SCHÄFER. 2019. Salinity impacts on river ecosystem processes: a critical mini-review. Philosophical Transactions of the Royal Society B: Biological Sciences, 374 (1764): 20180010. DOI: $10.1098 /$ rstb.2018.0010.

BERNER, R. A. 1971. Worldwide sulfur pollution of rivers. Journal of Geophysical Research, 76 (27): 6597-6600. DOI: 10.1029/JC076i027p06597

BHATT, M. P. \& W. H. MCDOWELL. 2007. Evolution of chemistry along the Bagmati drainage network in Kathmandu Valley. Water, Air, and Soil pollution, 185 (1-4): 165-176. DOI: 10.1007/s11270-007-9439-4

BIRD, D. L., P. M. GROFFMAN, C .J. SALICE \& J. MOORE. 2018. Steady-State Land Cover but Non-Steady-State Major Ion Chemistry in Urban Streams. Environmental Science \& Technology, 52 (22): 13015-13026. DOI: 10.1021/acs.est.8b03587

BLANKESPOOR, B., S. DASGUPTA \& B. LAPLANTE. 2012. Sea-level rise and coastal wetlands: impacts and costs. Washington DC, USA

BOGART, S. J., A. AZIZISHIRAZI \& G. G. PYLE. 2019. Challenges and future prospects for developing $\mathrm{Ca}$ and $\mathrm{Mg}$ water quality guidelines: a meta-analysis. Philosophical Transactions of the Royal Society B: Biological Sciences, 374 (1764): 20180364. DOI: 10.1098/rstb.2018.0364

BOYD, C. E., C. S. TUCKER \& B. SOMRIDHIVEJ. 2016. Alkalinity and hardness: critical but elusive concepts in aquaculture. Journal of the World Aquaculture Society, 47 (1): 6-41.

BRADLEY, T. J. 2008. Oxford Animal Biology 
Series: Animal osmorregulation. Oxford University Press . Oxford, UK.

BRAY, J. P., J. REICH, S. J. NICHOLS, G. KON KAM KING, R. MAC NALLY, R. THOMPSON, A. O'REILLY-NUGENT \& B. J. KEFFORD. 2019. Biological interactions mediate context and species-specific sensitivities to salinity. Philosophical Transactions of the Royal Society B: Biological Sciences, 374 (1764): 20180020. DOI: 10.1098/rstb.2018.0020 BRUCET, S., D. BOIX, X. D. QUINTANA, E. JENSEN, L. W. NATHANSEN, C. TROCHINE, M. MEERHOFF, S. GASCÓN \& E. JEPPESEN. 2010. Factors influencing zooplankton size structure at contrasting temperatures in coastal shallow lakes: implications for effects of climate change. Limnology and Oceanography, 55 (4): 1697. DOI: 10.4319/lo.2010.55.4.1697

BUCHWALTER, D., S. SCHEIBENER, H. CHOU, D. SOUCEK \& J. ELPHICK. 2019. Are sulfate effects in the mayfly Neocloeon triangulifer driven by the cost of ion regulation? Philosophical Transactions of the Royal Society B: Biological Sciences, 374 (1764): 20180013. DOI: $10.1098 / \mathrm{rstb} .2018 .0013$

BUSS, N. \& J. HUA. 2018. Parasite susceptibility in an amphibian host is modified by salinization and predators. Environmental Pollution, 236: 754-763. DOI: 10.1016/j.envpol.2018.01.060

CAÑEDO-ARGÜELLES, M., T. E. GRANTHAM, I. PERRÉE, M. RIERADEVALL, R. CÉSPEDES-SÁNCHEZ \& N. PRAT. 2012. Response of stream invertebrates to short-term salinization: A mesocosm approach. Environmental Pollution, 166: 144-151. DOI: 10.1016/j.envpol.2012.03.027

CAÑEDO-ARGÜELLES, M., B. J. KEFFORD, C. PISCART, N. PRAT, R. B. SCHÄFER \& C.-J. SCHULZ. 2013. Salinisation of rivers: an urgent ecological issue. Environmental Pollution, 173: 157-167. DOI: 10.1016/j.envpol. 2012.10.011

CAÑEDO-ARGÜELLES, M., M. BUNDSCHUH, C. GUTIÉRREZ-CÁNOVAS, B. J. KEFFORD, N. PRAT, R. TROBAJO \& R. B. SCHÄFER. 2014. Effects of repeated salt pulses on ecosystem structure and functions in a stream mesocosm. Science of the Total Envi- ronment, 476-477: 634-642. DOI: 10.1016/j. scitotenv.2013.12.067

CAÑEDO-ARGÜELLES, M., C. P. HAWKINS, B. J. KEFFORD, R. B. SCHÄFER, B. J. DYACK, S. BRUCET, D. BUCHWALTER, J. DUNLOP, O. FRÖR, J. LAZORCHAK, E. CORING, H. R. FERNANDEZ, W. GOODFELLOW, A. ACHEM, S. HATFIELD-DODDS, B. K. KARIMOV, P. MENSAH, J. R. OLSON, C. PISCART, N. PRAT, S. PONSÁ, C.-J. SCHULZ \& A. J. TIMPANO. 2016. Saving freshwater from salts. Science, 351(6276). DOI: 10.1126/science.aad3488

CAÑEDO-ARGÜELLES, M., S. BRUCET, S. CARRASCO, N. FLOR-ARNAU, M. ORDEIX, S. PONSÁ \& E. CORING. 2017. Effects of potash mining on river ecosystems: An experimental study. Environmental Pollution, 224: 759-770. DOI: 10.1016/j.envpol. 2016.12.072

CAÑEDO-ARGÜELLES, M., B. KEFFORD \& R. B. SCHÄFER. 2019. Salt in freshwaters: causes, effects and prospects - introduction to the theme issue. Philosophical Transactions of the Royal Society B: Biological Sciences, 374 (1764): 20180002.

CANHOTO, C., S. SIMÕES, A.L. GONÇALVES, L. GUILHERMINO \& F. BÄRLOCHER. 2017. Stream salinization and fungal-mediated leaf decomposition: A microcosm study. Science of The Total Environment 599: 1638-1645. DOI: 10.1098/rstb.2018.0002

CASTILlO, A. M., D. M. T. SHARPE, C. K. GHALAMBOR \& L. F. DE LEÓN. 2018. Exploring the effects of salinization on trophic diversity in freshwater ecosystems: a quantitative review. Hydrobiologia, 807 (1): 1-17. DOI: $10.1007 / \mathrm{s} 10750-017-3403-0$

CÉSPEDES, V., S. PALLARÉS, P. ARRIBAS, A. MILLÁN \& J. VELASCO. 2013. Water beetle tolerance to salinity and anionic composition and its relationship to habitat occupancy. Journal of Insect Physiology, 59 (10): 1076-84. DOI: 10.1016/j.jinsphys.2013.08.006

CLEMENTS, W. H. \& C. KOTALIK. 2016. Effects of major ions on natural benthic communities: an experimental assessment of the US Environmental Protection Agency aquatic life benchmark for conductivity. Freshwater Science, 
35 (1): 126-138. DOI: 10.1086/685085

COCHERO, J., M. LICURSI \& N. GÓMEZ. 2017.

Effects of pulse and press additions of salt on biofilms of nutrient-rich streams. Science of the Total Environment, 579: 1496-1503. DOI: 10.1016/j.scitotenv.2016.11.152

COLDSNOW, K. D., B. M. MATTES, W. D. HINTZ \& R. A. RELYEA. 2017a. Rapid evolution of tolerance to road salt in zooplankton. Environmental Pollution, 222: 367-373. DOI: 10.1016/j.envpol.2016.12.024

COLDSNOW, K. D., R. A. RELYEA \& J. M. HURLEY. 2017b. Evolution to environmental contamination ablates the circadian clock of an aquatic sentinel species. Ecology and Evolution, 7 (23): 10339-10349. DOI: 10.1002/ ece 3.3490

COOPER, C. A., P. M. MAYER \& B. R. FAULKNER. 2014. Effects of road salts on groundwater and surface water dynamics of sodium and chloride in an urban restored stream. Biogeochemistry, 121 (1): 149-166. DOI: $10.1007 / \mathrm{s} 10533-014-9968-\mathrm{z}$

CORING, E. \& J. BÄTHE. 2011. Effects of reduced salt concentrations on plant communities in the River Werra (Germany). Limnologica, 41 (2): 134-142. DOI: 10.1016/j.limno. 2010.08.004

CORMIER, S. M., G. W. SUTER \& L. ZHENG. 2013. Derivation of a benchmark for freshwater ionic strength. Environmental Toxicology and Chemistry, 32 (2): 263-71. DOI: 10.1002/etc. 2064

CORSI, S. R., D. J. GRACZYK, S. W. GEIS, N. L. BOOTH \& K. D. RICHARDS. 2010. A fresh look at road salt: aquatic toxicity and water-quality impacts on local, regional, and national scales. Environmental Science \& Technology, 44 (19): 7376-7382. DOI: 10.1021/es101333u

CRAFT, C., J. CLOUGH, J. EHMAN, S. JOYE, R. PARK, S. PENNINGS, H. GUO \& M. MACHMULLER. 2009. Forecasting the effects of accelerated sea-level rise on tidal marsh ecosystem services. Frontiers in Ecology and the Environment, 7 (2): 73-78. DOI: 10.1890/070219

DAI, A., T. QIAN, K. E. TRENBERTH \& J. D. MILLIMAN. 2009. Changes in Continental
Freshwater Discharge from 1948 to 2004. Journal of Climate, 22 (10): 2773-2792. DOI: 10.1175/2008JCLI2592.1

DASGUPTA, S., M. HUQ \& D. WHEELER. 2015. Drinking Water Salinity and Infant Mortality in Coastal Bangladesh. The World Bank. Available at: http://documents.worldbank.org/curated/ en/443761468006266910/Drinking-watersalinity-and-infant-mortality-in-coastalBangladesh

DE CASTRO-CATALÀ, N., I. MUÑOZ, L. ARMENDÁRIZ, B. CAMPOS, D. BARCELÓ, J. LÓPEZ-DOVAL, S. PÉREZ, M. PETROVIC, Y. PICÓ \& J. L. RIERA. 2015. Invertebrate community responses to emerging water pollutants in Iberian river basins. The Science of the Total Environment, 503-504: 142-50. DOI: 10.1016/j.scitotenv. 2014.06.110

DIKIO, E. D. 2010. Water quality evaluation of Vaal river, Sharpeville and Bedworth lakes in the Vaal region of south Africa. Research Journal of Applied Sciences, Engineering and Technology, 2(6): 574-579. ISSN: 2040-7467

DÖLL, P. \& H. M. SCHMIED. 2012. How is the impact of climate change on river flow regimes related to the impact on mean annual runoff? A global-scale analysis. Environmental Research Letters, 7 (1): 14037. DOI: 10.1088/1748-9326/7/1/014037

DONEY, S. C. 2010. The growing human footprint on coastal and open-ocean biogeochemistry. Science, 328 (5985): 1512-1516. DOI: $10.1126 /$ science. 1185198

DOWSE, R., C. G. PALMER, K. HILLS, F. TORPY \& B. J. KEFFORD. 2017. The mayfly nymph Austrophlebioides pusillus Harker defies common osmoregulatory assumptions. Royal Society Open Science, 4 (1): 160520. DOI: 10.1098/rsos. 160520

DUAN, S., S. S. KAUSHAL, P. M. GROFFMAN, L. E. BAND \& K. T. BELT. 2012. Phosphorus export across an urban to rural gradient in the Chesapeake Bay watershed. Journal of Geophysical Research: Biogeosciences, 117(G1). DOI: 10.1029/2011JG001782

DUAN, S. \& S. S. KAUSHAL. 2015. Salinization alters fluxes of bioreactive elements from stream ecosystems across land use. Biogeo- 
sciences, 12 (23): 7331-7347. DOI: 10.5194/ bg-12-7331-2015

DUGAN, H. A., S. L. BARTLETT, S. M. BURKE, J. P. DOUBEK, F. E. KRIVAK-TETLEY, N. K. SKAFF, J. C. SUMMERS, K. J. FARRELL, I. M. MCCULLOUGH \& A. M. MORALESWILLIAMS. 2017. Salting our freshwater lakes. Proceedings of the National Academy of Sciences, 114 (17): 4453-4458. DOI: 10.1073/pnas.1620211114

EAST, J. L., C. WILCUT \& A. A. PEASE. 2017. Aquatic food-web structure along a salinized dryland river. Freshwater Biology, 62 (4): 681-694. DOI: 10.1111/fwb.12893

EGGLISHAW, H. J. \& D. W. MACKAY. 1967. A survey of the bottom fauna of streams in the Scottish Highlands part III seasonal changes in the fauna of three streams. Hydrobiologia, 30 (3-4): 305-334. DOI: 10.1007/BF00964020

ELPHICK, J. R., M. DAVIES, G. GILRON, E. C. CANARIA, B. LO \& H. C. BAILEY. 2011. An aquatic toxicological evaluation of sulfate: The case for considering hardness as a modifying factor in setting water quality guidelines. Environmental Toxicology and Chemistry, 30 (1): 247-253. DOI: 10.1002/etc.363

ENTREKIN, S., M. EVANS-WHITE, B. JOHNSON \& E. HAGENBUCH. 2011. Rapid expansion of natural gas development poses a threat to surface waters. Frontiers in Ecology and the Environment, 9 (9): 503-511. DOI: 10.1890/110053

ENTREKIN, S. A., N. A. CLAY, M. ANASTASIA, H.-P. BROOKE \& M. A. EVANS-WHITE. 2019. Multiple riparian-stream connections are predicted to change in response to salinization. Philosophical Transactions of the Royal Society B: Biological Sciences, 374 (1764): 20180042. DOI: $10.1098 /$ rstb.2018.0042

ERICKSON, R. J. 1985. An evaluation of mathematical models for the effects of $\mathrm{pH}$ and temperature on ammonia toxicity to aquatic organisms. Water Research, 19 (8): 1047-1058. DOI: 10.1016/0043-1354(85) 90375-6

ESTÉVEZ, E., T. RODRÍGUEZ-CASTILLO, M. G.-F. ALEXIA, M. CAÑEDO-ARGÜELLES \& J. BARQUÍN. 2019. Drivers of spatio-tem- poral patterns of salinity in Spanish rivers: a nationwide assessment. Philosophical Transactions of the Royal Society B: Biological Sciences, 374 (1764): 20180022.

EZZATI, M., A. D. LOPEZ, A. RODGERS, S. VANDER HOORN, C. J. L. MURRAY \& COMPARATIVE RISK ASSESSMENT COLLABORATING GROUP. 2002. Selected major risk factors and global and regional burden of disease. The Lancet, 360 (9343): 1347-1360. DOI: 10.1016/S0140-6736(02) 11403-6

FELLET, G., L. MARCHIOL, G. DELLE VEDOVE \& A. PERESSOTTI. 2011. Application of biochar on mine tailings: effects and perspectives for land reclamation. Chemosphere, 83 (9): 1262-1267. DOI: 10.1016/j.chemosphere.2011.03.053

FERRAR, K. J., D. R. MICHANOWICZ, C. L. CHRISTEN, N. MULCAHY, S. L. MALONE \& R. K. SHARMA. 2013. Assessment of effluent contaminants from three facilities discharging Marcellus Shale wastewater to surface waters in Pennsylvania. Environmental Science \& Technology, 47 (7): 3472-3481. DOI: 10.1021/es301411q

FOLEY, J. A., R. DEFRIES, G. P. ASNER, C. BARFORD, G. BONAN, S. R. CARPENTER, F. S. CHAPIN, M. T. COE, G. C. DAILY \& H. K. GIBBS. 2005. Global consequences of land use. Science, 309 (5734): 570-574. DOI: 10.1126/science. 1111772

GARDNER, R. L. \& R. A. YOUNG. 1988. Assessing Strategies for Control of Irrigation-Induced Salinity in the Upper Colorado River Basin. American Journal of Agricultural Economics, 70 (1): 37. DOI: 10.2307/1241974

GIBB, N. P., J. J. DYNES \& W. CHANG. 2017. Synergistic desalination of potash brine-impacted groundwater using a dual adsorbent. Science of the Total Environment, 593: 99-108. DOI: 10.1016/j.scitotenv.2017.03.139

GONZÁLEZ ACHEM, A., M. L. ROLANDI \& H. R. FERNÁNDEZ. 2015. Saline waters and macroinvertebrates in subtropical Andean streams. Ecología austral, 25 (1): 26-36. ISSN: 1667-782X

GONÇALVES, A .L., A. CARVALHO, F. BÄRLOCHER \& C. CANHOTO. 2019b. Are 
fungal strains from salinized streams adapted to salt-rich conditions? Philosophical Transactions of the Royal Society B: Biological Sciences, 374 (1764): 20180018. DOI: 10.1098/ rstb.2018.0018

GONÇALVES, A. L., S. SIMÕES, F. BÄRLOCHER \& C. CANHOTO. 2019a. Leaf litter microbial decomposition in salinized streams under intermittency. Science of The Total Environment, 653: 1204-1212. DOI: 10.1016/j.scitotenv.2018.11.050

GOROSTIZA, S. 2014. Potash Extraction and Historical Environmental Conflict in the Bages Region (Spain). Investigaciones Geográficas, (61): 5-16. DOI: 10.14198/INGEO2014.61.01

GOROSTIZA, S. \& D. SAURI. 2017. Dangerous assemblages: Salts, trihalomethanes and endocrine disruptors in the water palimpsest of the Llobregat River, Catalonia. Geoforum, 81: 153-162. DOI: 10.1016/j.geoforum.2017.03.005

GOROSTIZA, S. \& D. SAURÍ. 2019. Naturalizing pollution: a critical social science view on the link between potash mining and salinization in the Llobregat river basin, northeast Spain. Philosophical Transactions of the Royal Society B: Biological Sciences, 374 (1764): 20180006. DOI: 10.1098/rstb.2018.0006

GRIFFITH, M. B. 2014. Natural variation and current reference for specific conductivity and major ions in wadeable streams of the conterminous USA. Freshwater Science, 33 (1): 1-17. DOI: 10.1086/674704

GRIFFITH, M. B. 2017. Toxicological perspective on the osmoregulation and ionoregulation physiology of major ions by freshwater animals: teleost fish, Crustacea, aquatic insects, and Mollusca. Environmental Toxicology and Chemistry, 36 (3): 576-600. DOI: 10.1002/etc. 3676

GROSELL, M., J. BLANCHARD, K. V. BRIX \& R. GERDES. 2007. Physiology is pivotal for interactions between salinity and acute copper toxicity to fish and invertebrates. Aquatic Toxicology, 84 (2): 162-172. DOI: 10.1016/j.aquatox.2007.03.026

GUDMUNDSSON, L., M. LEONARD, H. X. DO, S. WESTRA \& S. I. SENEVIRATNE. 2018. Observed Trends in Global Indicators of Mean and Extreme Streamflow. Geophys- ical Research Letters, 46. DOI: 10.1029/ 2018GL079725

GUTIÉRREZ-CÁNOVAS, C., D. SÁNCHEZFERNÁNDEZ, M. CAÑEDO-ARGÜELLES, A. MILLÁN, J. VELASCO, R. ACOSTA, P. FORTUÑO, N. OTERO, A. SOLER \& N. BONADA. 2019. Do all roads lead to Rome? Exploring community trajectories in response to anthropogenic salinization and dilution of rivers. Philosophical Transactions of the Royal Society B: Biological Sciences, 374 (1764): 20180009. DOI: 10.1098/rstb.2018.0009

GYPENS, N., G. LACROIX, C. LANCELOT \& A. V. BORGES. 2011. Seasonal and inter-annual variability of air-sea $\mathrm{CO} 2$ fluxes and seawater carbonate chemistry in the Southern North Sea. Progress in Oceanography, 88 (1-4): 59-77. DOI: 10.1016/j.pocean.2010.11.004

HALL, L. W. J. \& R. D. ANDERSON. 1995. The influence of salinity on the toxicity of various classes of chemicals to aquatic biota. Critical Reviews in Toxicology, 25 (4): 281-346. DOI: 10.3109/10408449509021613

HALLE, M., A. MÜLLER \& E. BELLACK. 2017. Schwellenwerte und Bioindikation zur gewässer-ökologischen Beurteilung des Salzgehalts von Fließgewässern gemäß EU-WRRL. Korrespondenz Wasserwirtschaft, 10 (9): 525-535. DOI: 10.3243/kwe2017.09.001

HALSE, S. A., J. K. RUPRECHT \& A. M. PINDER. 2003. Salinisation and prospects for biodiversity in rivers and wetlands of south-west Western Australia. Australian Journal of Botany, 51 (6): 673-688. DOI: 10.1071/BT02113

HAQ, S., S. S. KAUSHAL \& S. DUAN. 2018. Biogeochemistry, 141: 463. DOI: 10.1007/ s10533-018-0514-2

HAWKINS, C. P., J. R. OLSON \& R. A. HILL. 2010. The reference condition: predicting benchmarks for ecological and water-quality assessments. Journal of the North American Benthological Society, 29 (1): 312-343. DOI: 10.1899/09-092.1

HE, F. J. \& G. A. MACGREGOR. 2007. Salt, blood pressure and cardiovascular disease. Current Opinion in Cardiology, 22 (4): 298-305. DOI: 10.1097/HCO.0b013e32814fld8c

HERBERT, E. R., P. BOON, A. J. BURGIN, S. 
C. NEUBAUER, R. B. FRANKLIN, M. ARDÓN, K. N. HOPFENSPERGER, L. P. M. LAMERS \& P. GELL. 2015. A global perspective on wetland salinization: ecological consequences of a growing threat to freshwater wetlands. Ecosphere, 6 (10): 1-43. DOI: $10.1890 / E S 14-00534.1$

HERBST, D. B., S. W. ROBERTS \& R .B. MEDHURST. 2013. Defining salinity limits on the survival and growth of benthic insects for the conservation management of saline Walker Lake, Nevada, USA. Journal of Insect Conservation, 17 (5): 877-883. DOI: 10.1007/s10841-013-9568-6

HINTZ, W. D., B. M. MATTES, M. S. SCHULER, D. K. JONES, A. B. STOLER, L. LIND \& R. A. RELYEA. 2017. Salinization triggers a trophic cascade in experimental freshwater communities with varying food-chain length. Ecological Applications, 27 (3): 833-844. DOI: 10.1002/eap.1487

HINTZ, W. D. \& R. A. RELYEA. 2017. Impacts of road deicing salts on the early-life growth and development of a stream salmonid: Salt type matters. Environmental Pollution, 223: 409-415. DOI: 10.1016/j.envpol.2017.01.040

HINTZ, W. D., D. K. JONES \& R. A. RELYEA. 2019. Evolved tolerance to freshwater salinization in zooplankton: life-history trade-offs, cross-tolerance and reducing cascading effects. Philosophical Transactions of the Royal Society B: Biological Sciences, 374 (1764): 20180012. DOI: $10.1098 /$ rstb.2018.0012

HOGAN, A., R. VAN DAM, M. TRENFIELD \& A. HARFORD. 2012. Toxicity of single magnesium pulse exposures to tropical freshwater species. Internal Report 608, Supervising Scientist, Darwin, NT

HONEY-ROSES, J. \& D. W. SCHNEIDER. 2012. Regional Planning Ecosystem services in planning practice for urban and technologically advanced landscapes. $\mathrm{PhD}$ Thesis. University of Illinois at Urbana-Champaign.

HOPKINS, G. R., S. S. FRENCH \& E. D. BRODIE JR. 2013. Increased frequency and severity of developmental deformities in rough-skinned newt (Taricha granulosa) embryos exposed to road deicing salts $(\mathrm{NaCl}$ \& $\mathrm{MgCl} 2)$. Environmental Pollution, 173:
264-269. DOI: 10.1016/j.envpol.2012.10.002 HOPKINS, G. R. \& E. D. BRODIE. 2015. Occurrence of Amphibians in Saline Habitats: A Review and Evolutionary Perspective. Herpetological Monographs, 29 (1): 1-27. DOI: 10.1655/HERPMONOGRAPHS-D-14-00006 IPCC 2013. Climate Change 2013: The Physical Science Basis. Contribution of Working Group I to the Fifth Assessment Report of the Intergovernmental Panel on Climate Change. T. F. Stocker, D. Qin, G.-K. Plattner, M. Tignor, S.K. Allen, J. Boschung, A. Nauels, Y. Xia, and P. M. Midgley (eds.). Cambridge University Press, Cambridge, United Kingdom and New York, NY, USA.

JACKSON, M. C., C. J. G. LOEWEN, R. D. VINEBROOKE \& C. T. CHIMIMBA. 2016. Net effects of multiple stressors in freshwater ecosystems: a meta-analysis. Global Change Biology, 22 (1): 180-189. DOI: 10.1111/gcb. 13028

JACKSON, R. B. \& E. G. JOBBÁGY. 2005. From icy roads to salty streams. Proceedings of the National Academy of Sciences, 102 (41): 14487-14488. DOI: 10.1073/pnas.0507389102

JACKSON, J. J. \& D. H. FUNK. 2019. Temperature affects acute mayfly responses to elevated salinity: implications for toxicity of road de-icing salts. Philosophical Transactions of the Royal Society B: Biological Sciences, 374 (1764): 20180081. DOI: $10.1098 /$ rstb.2018.0081

JARDINE, A., P. SPELDEWINDE, S. CARVER \& P. WEINSTEIN. 2007. Dryland salinity and ecosystem distress syndrome: human health implications. EcoHealth, 4 (1): 10-17. DOI: 10.1007/s10393-006-0078-9

JEPPESEN, E., M. SØNDERGARD, A. R. PEDERSEN, K. JÜRGENS, A. STRZELCZAK, T. L. LAURIDSEN \& L. S. JOHANSSON. 2007. Salinity induced regime shift in shallow brackish lagoons. Ecosystems, 10: 47-57. DOI: $10.1007 / \mathrm{s} 10021-006-9007-6$

JEPPESEN, E., S. BRUCET, L. NASELLI-FLORES, E. PAPASTERGIADOU, K. STEFANIDIS, T. NÕGES, P. NÕGES, J. ATTAYDE, T. ZOHARY, J. COPPENS, T. BUCAK, R. MENEZES, F. FREITAS, M. KERNAN, M. SØNDERGAARD \& M. BEKLIOĞLU. 2015. Ecological impacts of 
global warming and water abstraction on lakes and reservoirs due to changes in water level and related changes in salinity. Hydrobiologia, 750 (1): 201-227. DOI: 10.1007/s10750-0142169-x

JEREMIAS, G., J. BARBOSA, S. M. MARQUES, K. A. C. DE SCHAMPHELAERE, F. VAN NIEUWERBURGH, D. DEFORCE, F. J. M. GONÇALVES, J. L. PEREIRA \& J. ASSELMAN. 2018. Transgenerational Inheritance of DNA Hypomethylation in Daphnia magna in Response to Salinity Stress. Environmental Science \& Technology, 52 (17): 10114-10123. DOI: 10.1021/acs.est.8b03225

JOHNSON, B. R., P. C. WEAVER, C. T. NIETCH, J. M. LAZORCHAK, K. A. STRUEWING \& D. H. FUNK. 2015. Elevated major ion concentrations inhibit larval mayfly growth and development. Environmental Toxicology and Chemistry, 34 (1): 167-172. DOI: 10.1002/etc.2777

JONES, E. \& M. T. H. VAN VLIET. 2018. Drought impacts on river salinity in the southern US: Implications for water scarcity. Science of The Total Environment, 644: 844-853. DOI: 10.1016/j.scitotenv.2018.06.373

KARAGIANNIS, I. C. \& P. G. SOLDATOS. 2008. Water desalination cost literature: review and assessment. Desalination, 223 (1-3): 448-456. DOI: 10.1016/j.desal.2007.02.071

KARIM, M. F. \& N. MIMURA. 2008. Impacts of climate change and sea-level rise on cyclonic storm surge floods in Bangladesh. Global Environmental Change, 18 (3): 490-500. DOI: 10.1016/j.gloenvcha.2008.05.002

KAUSHAL, S. S., P. M. GROFFMAN, G. E. LIKENS, K. T. BELT, W. P. STACK, V. R. KELLY, L. B. BAND \& G. T. FISHER. 2005. Increased salinization of fresh water in the northeastern United States. Proceedings of the National Academy of Science, 38 (38): 13517-13520. DOI: 10.1073/pnas.0506414102

KAUSHAL, S. S., G. E. LIKENS, R. M. UTZ, M. L. PACE, M. GRESE \& M. YEPSEN. 2013. Increased river alkalinization in the Eastern US. Environmental Science \& Technology, 47 (18): 10302-10311. DOI: 10.1021/es401046s

KAUSHAL, S. S., W. H. MCDOWELL \& W. M.
WOLLHEIM. 2014. Tracking evolution of urban biogeochemical cycles: past, present, and future. Biogeochemistry, 121 (1): 1-21.

KAUSHAL, S. S., W. H. MCDOWELL, W. M. WOLLHEIM, T. A. N. JOHNSON, P. M. MAYER, K. T. BELT \& M. J. PENNINO. 2015. Urban evolution: The role of water. Water, 7 (8): 4063-4087. DOI: 10.3390/ w7084063

KAUSHAL, S. S. 2016. Increased salinization decreases safe drinking water. Environmental Science \& Technology, 50: 2765-2766. DOI: 10.1021/acs.est.6b00679

KAUSHAL, S. S., S. DUAN, T. R. DOODY, S. HAQ, R. M. SMITH, T. A. N. JOHNSON, K. D. NEWCOMB, J. GORMAN, N. BOWMAN \& P. M. MAYER. 2017. Human-accelerated weathering increases salinization, major ions, and alkalinization in fresh water across land use. Applied geochemistry, 83: 121-135. DOI: 10.1016/j.apgeochem.2017.02.006

KAUSHAL, S. S., G. E. LIKENS, M. L. PACE, R. M. UTZ, S. HAQ, J. GORMAN \& M. GRESE. 2018. Freshwater salinization syndrome on a continental scale. Proceedings of the National Academy of Sciences, 115 (4): E574-E583. DOI: 10.1073/pnas.1711234115

KAUSHAL, S. S., G. E. LIKENS, M. L. PACE, H. SHAHAN, K. L. WOOD, J. G. GALELLA, M. CAROL, T. R. DOODY, W. BARRET, K. PIRKKO, R. ANTTI, S. VALERIE, U. RYAN \& J. NORBERT. 2019. Novel "chemical cocktails" in inland waters are a consequence of the freshwater salinization syndrome. Philosophical Transactions of the Royal Society B: Biological Sciences, 374 (1764): 20180017. DOI: 10.1098/rstb.2018.0017

KEFFORD, B. J., G. L. HICKEY, A. GASITH, E. BEN-DAVID, J. E. DUNLOP, C. G. PALMER, K. ALLAN, S. C. CHOY \& C. PISCART. 2012. Global scale variation in the salinity sensitivity of riverine macroinvertebrates: Eastern Australia, France, Israel and South Africa. PLoS ONE, 7 (5): e35224. DOI: 10.1371/journal.pone.0035224

KEFFORD, B. J., D. BUCHWALTER, M. CAÑEDO-ARGÜELLES, J. DAVIS, R. P. DUNCAN, A. HOFFMANN \& R. THOMPSON. 2016. Salinized rivers: degraded 
systems or new habitats for salt-tolerant faunas? Biology Letters, 12(3). DOI: 10.1098/rsbl.2015.1072

KEFFORD, B. J. 2019. Why are mayflies (Ephemeroptera) lost following small increases in salinity? Three conceptual osmophysiological hypotheses. Philosophical Transactions of the Royal Society B: Biological Sciences, 374 (1764): 20180021. DOI: 10.1098/rstb.2018.0021

KHAN, A. E., A. IRESON, S. KOVATS, S. K. MOJUMDER, A. KHUSRU, A. RAHMAN \& P. VINEIS. 2011. Drinking Water Salinity and Maternal Health in Coastal Bangladesh: Implications of Climate Change. Environmental Health Perspectives, 119 (9): 1328-1332. DOI: $10.1289 /$ ehp.1002804

KHAN, A. E., P. F. D. SCHEELBEEK, A. B. SHILPI, Q. CHAN, S. K. MOJUMDER, A. RAHMAN, A. HAINES \& P. VINEIS. 2014. Salinity in drinking water and the risk of (pre)eclampsia and gestational hypertension in coastal Bangladesh: a case-control study. PloS ONE, 9 (9): e108715. DOI: 10.1371/ journal.pone.0108715

KORETSKY, C. M., A. MACLEOD, R. J. SIBERT \& C. SNYDER. 2012. Redox stratification and salinization of three kettle lakes in southwest Michigan, USA. Water, Air, \& Soil Pollution, 223 (3): 1415-1427. DOI: 10.1007/s11270-011-0954-y

KRAUSMANN, F., S. GINGRICH, N. EISENMENGER, K.-H. ERB, H. HABERL \& M. FISCHER-KOWALSKI. 2009. Growth in global materials use, GDP and population during the 20th century. Ecological Economics, 68 (10): 2696-2705. DOI: 10.1016/j. ecolecon.2009.05.007

KUNZ, J. L., J. M. CONLEY, D. B. BUCHWALTER, T. J. NORBERG-KING, N. E. KEMBLE, N. WANG \& C. G. INGERSOLL. 2013. Use of reconstituted waters to evaluate effects of elevated major ions associated with mountaintop coal mining on freshwater invertebrates. Environmental Toxicology and Chemistry, 32 (12): 2826-2835. DOI: 10.1002/etc. 2391

KUPSCO, A., R. SIKDER \& D. SCHLENK. 2017. Comparative Developmental Toxicity of Desal- ination Brine and Sulfate-Dominated Saltwater in a Euryhaline Fish. Archives of Environmental Contamination and Toxicology, 72 (2): 294-302. DOI: 10.1007/s00244-016-0354-9

LADRERA, R., M. CAÑEDO-ARGÜELLES \& N. PRAT. 2017. Impact of potash mining in streams: The Llobregat basin (northeast Spain) as a case study. Journal of Limnology, 76 (2). DOI: 10.4081/jlimnol.2016.1525

LARSEN, E. H., L. E. DEATON, H. ONKEN, M. O'DONNELL, M. GROSELL, W. H. DANTZLER \& D. WEIHRAUCH. 2014. Osmoregulation and Excretion. Comprehensive Physiology, 4 (2): 405-573. DOI: 10.1002/cphy.c130004

LE, T. D. H., K. MIRA, S. KLAUS, J. R. OLSON, C. P. HAWKINS \& R. B. SCHÄFER. 2019. Predicting current and future background ion concentrations in German surface water under climate change. Philosophical Transactions of the Royal Society B: Biological Sciences, 374 (1764): 20180004. DOI: $10.1098 /$ rstb.2018.0004

LÉTOLLE, R. \& A. CHESTERIKOFF. 1999. Salinity of surface waters in the Aral sea region. International Journal of Salt Lake Research, 8 (4): 293-306. DOI: 10.1007/BF02442116

LOFGREN, S. 2001. The chemical effects of deicing salt on soil and stream water of five catchments in southeast Sweden. Water, Air and Soil Pollution, 130: 863-868. DOI: 10.1023/A:1013895215558

LOKHANDE, R. S., P. U. SINGARE \& D. S. PIMPLE. 2011. Study on physico-chemical parameters of waste water effluents from Taloja industrial area of Mumbai, India. International Journal of Ecosystem, 1 (1): 1-9. DOI: $10.5923 /$ j.ije.20110101.01

LOUREIRO, C., A. P. CUCO, M.T. CLARO, J. I. SANTOS, M. A. PEDROSA, F. GONÇALVES $\&$ B. B. CASTRO. 2015. Progressive acclimation alters interaction between salinity and temperature in experimental Daphnia populations. Chemosphere, 139: 126-132. DOI: 10.1016/j.chemosphere.2015.05.081

MACDONALD, A. M., H. C. BONSOR, K. M. AHMED, W. G. BURGESS, M. BASHARAT, R. C. CALOW, A. DIXIT, S. S. D. FOSTER, K. GOPAL \& D. J. LAP- 
WORTH. 2016. Groundwater quality and depletion in the Indo-Gangetic Basin mapped from in situ observations. Nature Geoscience, 9 (10): 762-766. DOI: 10.1038/ngeo2791

MAHMUDUZZAMAN, M., Z. U. AHMED, A. K. M. NURUZZAMAN \& F. R. S. AHMED. 2014. Causes of Salinity Intrusion in Coastal Belt of Bangladesh. International Journal of Plant Research, 4 (4A): 8-13. DOI: 10.5923/s.plant.201401.02

MARGALEF, R.. 1986. Ecología. Quinta reimpresión. Ediciones Omega. Barcelona, Spain. ISBN: 84-282-0405-5.

MARION, G. M., C.H. FRITSEN, H. EICKEN $\&$ M. C. PAYNE. 2003. The search for life on Europa: limiting environmental factors, potential habitats, and Earth analogues. Astrobiology, 3 (4): 785-811. DOI: 10.1089/153110703322736105

MARTÍN-ALONSO, J. 1994. Barcelona's water supply improvement: the brine collector of the Llobregat river. Water Science and Technology, 30 (10): 221-227. DOI: 10.2166/wst.1994.0531

MAST, M. A. 2013. Evaluation of stream chemistry trends in US Geological Survey reference watersheds, 1970-2010. Environmental Monitoring and Assessment, 185 (11): 9343-9359. DOI: $10.1007 / \mathrm{s} 10661-013-3256-6$

MENDEZ, M. O. \& R. M. MAIER. 2008. Phytostabilization of mine tailings in arid and semiarid environments - an emerging remediation technology. Environmental Health Perspectives, 116 (3): 278. DOI: 10.1289/ehp.10608

MEYBECK, M. 2003. Global analysis of river systems: from Earth system controls to Anthropocene syndromes. Philosophical Transactions of the Royal Society B: Biological Sciences, 358 (1440): 1935-1955. DOI: 10.1098/rstb.2003.1379

MEYBECK, M. \& R. HELMER. 1989. The quality of rivers: from pristine stage to global pollution. Global and Planetary Change, 1 (4): 283-309. DOI: 10.1016/0031-0182(89) 90191-0

MICKLIN, P. 2007. The Aral Sea Disaster. Annual Review of Earth and Planetary Sciences, 35 (1): 47-72. DOI: 10.1146/annurev.earth. 35.031306.140120

MIGHANETARA, K., C. B. BRAUNGARDT, J.
S. RIEUWERTS \& F. AZIZI. 2009. Contaminant fluxes from point and diffuse sources from abandoned mines in the River Tamar catchment, UK. Journal of Geochemical Exploration, 100 (2-3): 116-124. DOI: 10.1016/j.gexplo.2008.03.003

MILLÁN, A., J. VELASCO, C. GUTIÉRREZ-CÁNOVAS, P. ARRIBAS, F. PICAZO, D. SÁNCHEZ-FERNÁNDEZ \& P. ABELLÁN. 2011. Mediterranean saline streams in southeast Spain: What do we know? Journal of Arid Environments, 75 (12): 1352-1359. DOI: 10.1016/j.jaridenv.2010.12.010

MIN, J.-Y. \& K.-B. MIN. 2016. Blood trihalomethane levels and the risk of total cancer mortality in US adults. Environmental Pollution, 212: 90-96. DOI: 10.1016/j.envpol. 2016.01.047

MINSHALL, G. W. \& R. A. KUEHNE. 1969. Ecological study of invertebrates of the duddon, an English mountain stream. Archiv für Hydrobiologie, 66: 169-191.

MIRZA, M. M. Q. 1998. Diversion of the Ganges Water at Farakka and Its Effects on Salinity in Bangladesh. Environmental Management 22 (5): 711-722. DOI: 10.1007/s002679900141

MOHAMED, E. S. \& G. PAPADAKIS. 2004. Design, simulation and economic analysis of a stand-alone reverse osmosis desalination unit powered by wind turbines and photovoltaics. Desalination, 164 (1): 87-97. DOI: 10.1016/S0011-9164(04)00159-6

MOORE, J., D. L. BIRD, S. K. DOBBIS \& G. WOODWARD. 2017. Nonpoint Source Contributions Drive Elevated Major Ion and Dissolved Inorganic Carbon Concentrations in Urban Watersheds. Environmental Science \& Technology Letters, 4 (6): 198-204. DOI: 10.1021/acs.estlett.7b00096

MOQUET, J.-S., L. MAURICE, A. CRAVE, J. VIERS, N. AREVALO, C. LAGANE, W. LAVADO-CASIMIRO \& J.-L. GUYOT. 2014. $\mathrm{Cl}$ and $\mathrm{Na}$ Fluxes in an Andean Foreland Basin of the Peruvian Amazon: An Anthropogenic Impact Evidence. Aquatic Geochemistry, 20 (6): 613-637. DOI: 10.1007/ s10498-014-9239-6

MOUNT, D. R., D. D. GULLEY, J. R. HOCKETT, T. D. GARRISON \& J. M. EVANS. 
1997. Statistical models to predict the toxicity of major ions to Ceriodaphnia dubia, Daphnia magna and Pimephales promelas (fathead minnows). Environmental Toxicology and Chemistry, 16 (10): 2009-2019. DOI: 10.1002/etc.5620161005

MOUNT, D. R., R.J. ERICKSON, T. L. HIGHLAND, J. R. HOCKETT, D. J. HOFF, C. T. JENSON, T. J. NORBERG-KING, K. N. PETERSON, Z. M. POLASKE \& S. WISNIEWSKI. 2016. The acute toxicity of major ion salts to Ceriodaphnia dubia: I. Influence of background water chemistry. Environmental toxicology and chemistry, 35 (12): 3039-3057. DOI: 10.1002/etc.3487

NAFEY, A. S., M. A. SHARAF \& L. GARCÍA-RODRÍGUEZ. 2010. Thermo-economic analysis of a combined solar organic Rankine cycle-reverse osmosis desalination process with different energy recovery configurations. Desalination, 261 (1-2): 138-147. DOI: $10.1016 /$ j.desal.2010.05.017

NIRGUDE, N. T., S. SHUKLA \& A. VENKATACHALAM. 2013. Physico-chemical analysis of some industrial effluents from Vapi industrial area, Gujarat, India. Rasayan Journal of Chemistry, 6: 68-72. ISSN: 0974-1496

NOVOTNY, E. V., D. MURPHY \& H. G. STEFAN. 2008. Increase of urban lake salinity by road deicing salt. Science of the Total Environment, 406 (1-2): 131-144. DOI: 10.1016/j.scitotenv.2008.07.037

OBER, J. A. 2018. Mineral commodity summaries 2018. US Geological Survey. Available at: https://minerals.usgs.gov/minerals/pubs/mcs/ 2018/mcs2018.pdf

OLMSTEAD, S. M., L. A. MUEHLENBACHS, J.-S. SHIH, Z. CHU \& A. J. KRUPNICK. 2013. Shale gas development impacts on surface water quality in Pennsylvania. Proceedings of the National Academy of Sciences of the United States of America, 110 (13): 4962-7. DOI: 10.1073/pnas.1213871110

OLSON, J. R. 2019. Predicting combined effects of land use and climate change on river and stream salinity. Philosophical Transactions of the Royal Society B: Biological Sciences, 374 (1764): 20180005. DOI: $10.1098 / \mathrm{rstb} .2018 .0005$

ORMEROD, S. J., M. DOBSON, A. G.
HILDREW \& C. TOWNSEND. 2010. Multiple stressors in freshwater ecosystems. Freshwater Biology, 55 (s1): 1-4. DOI: 10.1111/j. 1365-2427.2009.02395.x

OSMAN, O., O. D. AINA \& F. AHMAD. 2017. Chemical fingerprinting of saline water intrusion into sewage lines. Water Science and Technology, 76 (8): 2044-2050. DOI: 10.2166/wst.2017.374

OTERO, N. \& A. SOLER. 2002. Sulphur isotopes as tracers of the influence of potash mining in groundwater salinisation in the Llobregat Basin (NE Spain). Water Research, 36 (16): 3989-4000. DOI: 10.1016/S00431354(02)00125-2

PALLARÉS, S., J. VELASCO, A. MILLÁN, D. T. BILTON \& P. ARRIBAS. 2016. Aquatic insects dealing with dehydration: do desiccation resistance traits differ in species with contrasting habitat preferences? PeerJ, 4: e2382. DOI: $10.7717 /$ peerj.2382

PALLARÉS, S., M. BOTELLA-CRUZ, P. ARRIBAS, A. MILLÁN \& J. VELASCO. 2017. Aquatic insects in a multistress environment: cross-tolerance to salinity and desiccation. Journal of Experimental Biology, 220 (7): 1277-1286. DOI: 10.1242/jeb.152108

PATTERSON, L. A., K.E. KONSCHNIK, H. WISEMAN, J. FARGIONE, K. O. MALONEY, J. KIESECKER, J.-P. NICOT, S. BARUCH-MORDO, S. ENTREKIN, A. TRAINOR \& J. E. SAIERS. 2017. Unconventional Oil and Gas Spills: Risks, Mitigation Priorities, and State Reporting Requirements. Environmental Science \& Technology, 51 (5): 2563-2573. DOI: 10.1021/acs.est.6b05749

PAUL, W. L., R. A. COOK, P. J. SUTER, K. R. CLARKE, M. E. SHACKLETON, P. J. MCINERNEY \& J. H. HAWKING. 2018. Long-Term Monitoring of Macroinvertebrate Communities Over 2,300 km of the Murray River Reveals Ecological Signs of Salinity Mitigation Against a Backdrop of Climate Variability. Water Resources Research, 54 (9): 7004-7028. DOI: 10.1029/2018WR022976

PEREIRA, L. S., J. M. GONÇALVES, B. DONG, Z. MAO \& S. X. FANG. 2007. Assessing basin irrigation and scheduling strategies for saving irrigation water and 
controlling salinity in the upper Yellow River Basin, China. Agricultural Water Management, 93 (3): 109-122. DOI: 10.1016/j.agwat. 2007.07.004

PEREIRA, C. S., I. LOPES, I. ABRANTES, P. J. SOUSA \& S. CHELINHO. 2019. Salinization effects on coastal ecosystems: a terrestrial model ecosystem approach. Philosophical Transactions of the Royal Society B: Biological Sciences, 374 (1764): 20180251. DOI: 10.1098/rstb.2018.0251

PFITZNER, K. S., A. J. HARFORD, T. G. WHITESIDE \& R. E. BARTOLO. 2018. Mapping magnesium sulfate salts from saline mine discharge with airborne hyperspectral data. Science of The Total Environment, 640-641: 1259-1271. DOI: 10.1016/j.scitotenv.2018. 05.396

PINDER, A. M., S. A. HALSE, J. M. MCRAE \& R. J. SHIEL. 2005. Occurrence of aquatic invertebrates of the wheatbelt region of Western Australia in relation to salinity. Hydrobiologia, 543: 1-24. DOI: 10.1007/s10750-004$5712-3$

PINTO, P. X., S. R. AL-ABED, D. A. BALZ, B. A. BUTLER, R. B. LANDY \& S. J. SMITH. 2016. Bench-scale and pilot-scale treatment technologies for the removal of total dissolved solids from coal mine water: a review. Mine Water and the Environment, 35 (1): 94-112. DOI: $10.1007 / \mathrm{s} 10230-015-0351-7$

PISCART, C., J.-C. MORETEAU \& J.-N. BEISEL. 2005. Biodiversity and structure of macroinvertebrate communities along a small permanent salinity gradient (Meurthe River, France). Hydrobiologia, 551: 227-236.

PISCART, C., P. USSEGLIO-POLATERA, J.-C. MORETEAU \& J.-N. BEISEL. 2006. The role of salinity in the selection of biological traits of freshwater invertbrates. Archiv für Hydrobiologie, 166 (2): 185-198. DOI: 10.1007/s10750-005-4463-0

PITMAN, M. G. \& A. LÄUCHLI. 2002. Global impact of salinity and agricultural ecosystems. In: Salinity: environment-plants-molecules. 3-20. Springer.

POND, G. J., M. E. PASSMORE, F. A. BORSUK, L. REYNOLDS \& C. J. ROSE. 2008. Downstream effects of mountaintop coal mining: comparing biological conditions using family- and genus-level macroinvertebrate bioassessment tools. Journal of the North American Benthological Society, 27 (3): 717-737. DOI: 10.1899/08-015.1

POTAPOVA, M. \& D. F. CHARLES. 2003. Distribution of benthic diatoms in U.S. rivers in relation to conductivity and ioic composition. Freshwater Biology, 48: 1311-1328. DOI: 10.1046/j.1365-2427.2003.01080.x

POTEAT, M. D. \& D. B. BUCHWALTER. 2014. Calcium uptake in aquatic insects: influences of phylogeny and metals (Cd and Zn). Journal of Experimental Biology, 217 (7): 1180-1186. doi: 1180-1186; DOI: 10.1242/jeb.097261

QUEENSLAND GOVERNMENT. 2011. Salinity management handbook. Brisbane, Australia RANKIN, J. C. \& J. DAVENPORT. 1981. Animal osmoregulation. Halsted Press. New York.

RAUCHE, H. A. M., D. FULDA \& V. SCHWALM. 2001. Tailings and Disposal Brine Reduction-Design Criteria for Potash Production in the 21 st Century. In: Tailings and mine waste. 85-91.

REMANE, A. \& C. SCHLIEPER. 1971. Biology of brackish water. Wiley Interscience. New York.

ROMANO, N., F. SYUKRI, A. KARAMI, N. OMAR \& N. KHALID. 2017. Salinity-induced changes to the survival, growth and glycogen distribution in the early fry stages of silver barb, Barbodes gonionotus (Bleeker, 1850). Journal of Applied Ichthyology, 33 (3): 509-514. DOI: 10.1111/jai.13338

ROZELL, D. J. \& S. J. REAVEN. 2012. Water pollution risk associated with natural gas extraction from the Marcellus Shale. Risk Analysis, 32 (8): 1382-1393. DOI: 10.1111/j. 1539-6924.2011.01757.x

RUNTTI, H., E.-T. TOLONEN, S. TUOMIKOSKI, T. LUUKKONEN \& U. LASSI. 2018. How to tackle the stringent sulfate removal requirements in mine water treatment-A review of potential methods. Environmental Research, 167: 207-222. DOI: 10.1016/j.envres.2018.07.018

RUTH, O. 2003. The effects of de-icing in Helsinki urban streams, southern Finland. Water Science and Technology, 48 (9): 33-43. DOI: 10.2166/wst.2003.0486 
SALA, M., M. FARIA, I. SARASÚA, C. BARATA, N. BONADA, S. BRUCET, L. LLENAS, S. PONSÁ, N. PRAT, A. M. V. M. SOARES \& M. CAÑEDO-ARGUELLES. 2016. Chloride and sulphate toxicity to Hydropsyche exocellata (Trichoptera, Hydropsychidae): Exploring intraspecific variation and sub-lethal endpoints. Science of the Total Environment, 566-567.

SÁNCHEZ-FERNÁNDEZ, D., D. T. BILTON, P. ABELLÁN, I. RIBERA, J. VELASCO \& A. MILLÁN. 2008. Are the endemic water beetles of the Iberian Peninsula and the Balearic Islands effectively protected? Biological Conservation, 141 (6): 1612-1627. DOI: 10.1016/j.biocon.2008.04.005

SAUER, F. G., M. BUNDSCHUH, J. P. ZUBROD, R. B. SCHÄFER, K. THOMPSON \& B. J. KEFFORD. 2016. Effects of salinity on leaf breakdown: dryland salinity versus salinity from a coalmine. Aquatic Toxicology, 177: 425-432. DOI: 10.1016/j.aquatox.2016. 06.014

SCHÄFER, R. B., B. J. KEFFORD, L. METZELING, M. LIESS, S. BURGERT, R. MARCHANT, V. PETTIGROVE, P. GOONAN \& D. NUGEGODA. 2011. A trait database of stream invertebrates for the ecological risk assessment of single and combined effects of salinity and pesticides in South-East Australia. Science of The Total Environment, 409: 2055-2063. DOI: 10.1016/j.scitotenv.2011.01.053

SCHÄFER， R. B., M. BUNDSCHUH， D. ROACH, E. SZÖCS, P. C. VON DER OHE, V. PETTIGROVE, R. SCHULZ, D. NUGEGODA \& B. J. KEFFORD. 2012. Relationships of selected ecosystem functions in streams with pesticide toxicity, salinity and other environmental variables and the relevance for ecosystem services. Science of The Total Environment, 415: 69-78. DOI: 10.1016/j.scitotenv.2011.05.063

SCHEELBEEK, P. F. D., A. E. KHAN, S. MOJUMDER, P. ELLIOTT \& P. VINEIS. 2016. Drinking Water Sodium and Elevated Blood Pressure of Healthy Pregnant Women in Salinity-Affected Coastal AreasNovelty and Significance. Hypertension, 68 (2): 464-470.
DOI: 10.1161/HYPERTENSIONAHA.116. 07743

SCHEIBENER, S. A., V. S. RICHARDI \& D. B. BUCHWALTER. 2016. Comparative sodium transport patterns provide clues for understanding salinity and metal responses in aquatic insects. Aquatic Toxicology, 171: 20-29. DOI: 10.1016/j.aquatox.2015.12.006

SCHEIBENER, S., J. M. CONLEY \& D. BUCHWALTER. 2017. Sulfate transport kinetics and toxicity are modulated by sodium in aquatic insects. Aquatic Toxicology, 190: 62-69. DOI: 10.1016/j.aquatox.2017.06.027

SCHERMAN, P.-A. A., W. J. MULLER \& C. G. PALMER. 2003. Links between ecotoxicology, biomonitoring and water chemistry in the integration of water quality into environmental flow assessments. River Research and Applications, 19 (5-6): 483-493. DOI: 10.1002/ rra. 751

SCHULER, M. S., W. D. HINTZ, D. K. JONES, L. A. LIND, B. M. MATTES, A. B. STOLER, K. A. SUDOL \& R. A. RELYEA. 2017. How common road salts and organic additives alter freshwater food webs: in search of safer alternatives. Journal of Applied Ecology, 54 (5): 1353-1361. DOI: 10.1111/1365-2664.12877

SCHULER, M. S. \& R. A. RELYEA. 2018. A Review of the Combined Threats of Road Salts and Heavy Metals to Freshwater Systems. BioScience, 68 (5): 327-335. DOI: 10.1093/biosci/biy018

SCHULER, M. S., M. CAÑEDO-ARGÜELLES, W. D. HINTZ, B. DYACK, S. BIRK \& R. A. RELYEA. 2019. Regulations are needed to protect freshwater ecosystems from salinization. Philosophical Transactions of the Royal Society B: Biological Sciences, 374 (1764): 20180019. DOI: 10.1098/rstb.2018.0019

SCHULZ, C.-J. 2016. How does salinisation running waters affect aquatic communities? Answers from a case study. In: Proceedings IMWA 2016, Mining Meets Water-Conflicts and Solutions. C. Drebenstedt and M. Paul (eds.): 144-150. Freiberg, Germany.

SCHULZ, C.-J., \& M. CAÑEDO-ARGÜELLES. 2019. Lost in translation: the German literature on freshwater salinization. Philosophical Transactions of the Royal Society B: Biologi- 
cal Sciences, 374 (1764): 20180007. DOI: 10.1098/rstb.2018.0007

SHAFFER, D. L., L. H. ARIAS CHAVEZ, M. BEN-SASSON, S. ROMERO-VARGAS CASTRILLÓN, N. Y. YIP \& M. ELIMEL$\mathrm{ECH}$. 2013. Desalination and reuse of high-salinity shale gas produced water: drivers, technologies, and future directions. Environmental Science \& Technology, 47 (17): 9569-9583. DOI: 10.1021/es401966e

SMYNTEK, P. M., R. C. WAGNER, L.-A. KROMETIS, S. C. SANCHEZ, T. WYNN-THOMPSON \& W. H. J. STROSNIDER. 2017. Passive Biological Treatment of Mine Water to Reduce Conductivity: Potential Designs, Challenges, and Research Needs. Journal of Environmental Quality, 46 (1): 1-9. DOI: 10.2134/jeq2016.06.0216

SNODGRASS, J. W., J. MOORE, S. M. LEV, R. E. CASEY, D. R. OWNBY, R. F. FLORA \& G. IZZO. 2017. Influence of Modern Stormwater Management Practices on Transport of Road Salt to Surface Waters. Environmental Science \& Technology, 51 (8): 4165-4172. DOI: 10.1021/acs.est.6b03107

SONG, M. Y., J. D. STARK \& J. J. BROWN. 1997. Comparative toxicity of four insecticides, including imidacloprid and tebufenozide, to four aquatic arthropods. Environmental Toxicology and Chemistry, 16 (12): 2494-2500. DOI: $10.1002 /$ etc.5620161209

SOUCEK, D. J. \& A. J. KENNEDY. 2005. Effects of hardness, chloride, and acclimation on the acute toxicity of sulfate to freshwater invertebrates. Environmental Toxicology and Chemistry, 24 (5): 1204-1210. DOI: 10.1897/ 04-142.1

SOUCEK, D. J. 2007a. Bioenergetic effects of sodium sulfate on the freshwater crustacean, Ceriodaphnia dubia. Ecotoxicology, 16 (3): 317-325. DOI: 10.1007/s10646-007-0133-5

SOUCEK, D. J. 2007b. Comparison of hardness-and chloride-regulated acute effects of sodium sulfate on two freshwater crustaceans. Environmental Toxicology and Chemistry, 26 (4): 773-779. DOI: 10.1897/06-229R.1

SOUCEK, D. J. 2007c. Sodium sulfate impacts feeding, specific dynamic action, and growth rate in the freshwater bivalve Corbicula fluminea. Aquatic toxicology, 83 (4): 315-322. DOI: 10.1016/j.aquatox.2007.05.006

SOUCEK, D. J. \& A. DICKINSON. 2015. Full-life chronic toxicity of sodium salts to the mayfly Neocloeon triangulifer in tests with laboratory cultured food. Environmental Toxicology and Chemistry, 34 (9): 2126-2137. DOI: $10.1002 /$ etc. 3038

SOUCEK, D. J., T. K. LINTON, C. D. TARR, A. DICKINSON, N. WICKRAMANAYAKE, C. G. DELOS \& L. A. CRUZ. 2011. Influence of water hardness and sulfate on the acute toxicity of chloride to sensitive freshwater invertebrates. Environmental Toxicology and Chemistry, 30 (4): 930-938. DOI: 10.1002/etc.454

SOUCEK, D. J., D. R. MOUNT, A. DICKINSON \& J. R. HOCKETT. 2018. Influence of dilution water ionic composition on acute major ion toxicity to the mayfly Neocloeon triangulifer. Environmental Toxicology and Chemistry, 37 (5): 1330-1339. DOI: 10.1002/etc.4072

STĂNESCU, F., D. SZÉKELY, P. SZÉKELY, S. TOPLICEANU \& D. COGĂLNICEANU. 2017. The impact of salinity on early developmental stages in two sympatric spadefoot toads and implications for amphibian conservation in coastal areas. Hydrobiologia, 792 (1): 357-366. DOI: 10.1007/s10750-016-3074-2

STEELE, M. K. \& J. A. AITKENHEAD-PETERSON. 2013. Salt impacts on organic carbon and nitrogen leaching from senesced vegetation. Biogeochemistry, 112 (1-3): 245-259. DOI: 10.1007/s10533-012-9722-3

SUÁREZ, M. L., M. M. SÁNCHEZ-MONTOYA, R. GÓMEZ, M. I. ARCE, R. DEL CAMPO \& M. R. VIDAL-ABARCA. 2017. Functional response of aquatic invertebrate communities along two natural stress gradients (water salinity and flow intermittence) in Mediterranean streams. Aquatic Sciences, 79 (1): 1-12. DOI: 10.1007/s00027-016-0475-2

SZÖCS, E., B. J. KEFFORD \& R. B. SCHÄFER. 2012. Is there an interaction of the effects of salinity and pesticides on the community structure of macroinvertebrates? Science of The Total Environment, 437: 121-126. DOI: 10.1016/j.scitotenv.2012.07.066

SZÖCS, E., E. CORING, J. BÄTHE \& R. B. SCHÄFER. 2014. Effects of anthropogenic 
salinization on biological traits and community composition of stream macroinvertebrates. Science of The Total Environment, 468 (0): 943-949. DOI: 10.1016/j.scitotenv.2013.08.058

TASKER, T. L., W. D. BURGOS, P. PIOTROWSKI, L. CASTILLO-MEZA, T. A. BLEWETT, K. B. GANOW, A. STALLWORTH, P. L. M. DELOMPRÉ, G. G. GOSS, L. B. FOWLER, J. P. VANDEN HEUVEL, F. DORMAN \& N. R. WARNER. 2018. Environmental and Human Health Impacts of Spreading Oil and Gas Wastewater on Roads. Environmental Science \& Technology, 52 (12): 7081-7091. DOI: 10.1021/acs.est.8b00716

TIMPANO, A. J., S. H. SCHOENHOLTZ, D. J. SOUCEK \& C. E. ZIPPER. 2018. Benthic macroinvertebrate community response to salinization in headwater streams in Appalachia USA over multiple years. Ecological Indicators, 91: 645-656. DOI: 10.1016/j.ecolind.2018. 04.031

TIMPANO, A. J., C. E. ZIPPER, D. J. SOUCEK \& S. H. SCHOENHOLTZ. 2018. Seasonal pattern of anthropogenic salinization in temperate forested headwater streams. Water Research, 133: 8-18. DOI: 10.1016/j.watres. 2018.01.012

URS. 2014. Comprehensive Planning Studies for Salinity Control Measure in the Upper Colorado River Basin. Uinta Basin, Utah. Available at: https://www.coloradoriversalinity.org/ docs/Uinta\%20Basin\%20-\%20Final\%20 Report\%20complete.pdf

VAN DAM, R. A., A. C. HOGAN, C. D. MCCULlOUGH, M. A. HOUSTON, C. L. HUMPHREY \& A. J. HARFORD. 2010. Aquatic toxicity of magnesium sulfate, and the influence of calcium, in very low ionic concentration water. Environmental Toxicology and Chemistry, 29 (2): 410-421. DOI: 10.1002/etc.56

VAN DAM, R. A., A. J. HARFORD, S. A. LUNN \& M. M. GAGNON. 2014. Identifying the cause of toxicity of a saline mine water. PloS ONE, 9 (9): e106857. DOI: 10.1371/ journal.pone.0106857

VANDER LAAN, J. J., C. P. HAWKINS, J. R. OLSON \& R. A. HILL. 2013. Linking land use, in-stream stressors, and biological condi- tion to infer causes of regional ecological impairment in streams. Freshwater Science, 32 (3): 801-820. DOI: 10.1899/12-186.1

VELASCO, J., A. MILLÁN, J. HERNÁNDEZ, C. GUTIÉRREZ, P. ABELLÁN, D. SÁNCHEZ \& M. RUIZ. 2006. Response of biotic communities to salinity changes in a Mediterranean hypersaline stream. Saline Systems, 2: 12. DOI: 10.1186/1746-1448-2-12 VELASCO, J., C. GUTIÉRREZ-CÁNOVAS, MARÍA BOTELLA-CRUZ, D. SÁNCHEZFERNÁNDEZ, P. ARRIBAS, J. A. CARBONELL, A. MILLÁN \& S. PALLARÉS. 2019. Effects of salinity changes on aquatic organisms in a multiple stressor context. Philosophical Transactions of the Royal Society B: Biological Sciences, 374 (1764): 20180011. DOI: 10.1098/rstb.2018.0011

VENÂNCIO, C., B. B. CASTRO, R. RIBEIRO, C. S. ANTUNES, N. ABRANTES, A. M. V. M. SOARES \& I. LOPES. 2019. Sensitivity of freshwater species under single and multigenerational exposure to seawater intrusion. Philosophical Transactions of the Royal Society B: Biological Sciences, 374 (1764): 20180252. DOI: $10.1098 /$ rstb.2018.0252

VENGOSH, A., R. B. JACKSON, N. WARNER, T. H. DARRAH \& A. KONDASH. 2014. A critical review of the risks to water resources from unconventional shale gas development and hydraulic fracturing in the United States. Environmental Science \& Technology, 48 (15): 8334-8348. DOI: 10.1021/es405118y

VIDIC, R. D., S. L. BRANTLEY, J. M. VANDENBOSSCHE, D. YOXTHEIMER \& J. D. ABAD. 2013. Impact of shale gas development on regional water quality. Science, 340 (6134): 1235009. DOI: 10.1126/science. 1235009

VILLASTRIGO, A., H. FERY, M. MANUEL, A. MILLÁN \& I. RIBERA. 2018. Evolution of salinity tolerance in the diving beetle tribe Hygrotini (Coleoptera, Dytiscidae). Zoologica Scripta, 47 (1): 63-71. DOI: 10.1111/zsc.12255

VINEIS, P., Q. CHAN \& A. KHAN. 2011. Climate change impacts on water salinity and health. Journal of Epidemiology and Global Health, 1 (1): 5-10. DOI: 10.1016/j.jegh.2011. 09.001 
VÖRÖSMARTY, C. J., P. GREEN, J. SALISBURY \& R. B. LAMMERS. 2000. Global water resources: vulnerability from climate change and population growth. Science, 289 (5477): 284-288. DOI: 10.1126/science.289. 5477.284

WALSH, C. J., A. H. ROY, J. W. FEMINELLA, P. D. COTTINGHAM, P. M. GROFFMAN \& R. P. MORGAN. 2005. The urban stream syndrome: current knowledge and the search for a cure. Journal of the North American Benthological Society, 24: 706-723. DOI: 10.1899/04-028.1

WANG, N., R. A. DORMAN, C. G. INGERSOLL, D. K. HARDESTY, W. G. BRUMBAUGH, E. J. HAMMER, C. R. BAUER \& D. R. MOUNT. 2016. Acute and chronic toxicity of sodium sulfate to four freshwater organisms in water-only exposures. Environmental Toxicology and Chemistry, 35 (1): 115-127. DOI: $10.1002 /$ etc. 3148

WANG, Y., S. TAVAKKOLI, V. KHANNA, R. D. VIDIC \& L. M. GILBERTSON. 2018. Life Cycle Impact and Benefit Trade-Offs of a Produced Water and Abandoned Mine Drainage Cotreatment Process. Environmental Science \& Technology, 52 (23): 13995-14005. DOI: 10.1021/acs.est.8b03773

WARNER, N. R., C. A. CHRISTIE, R. B. JACKSON \& A. VENGOSH. 2013. Impacts of Shale Gas Wastewater Disposal on Water Quality in Western Pennsylvania. Environmental Science \& Technology, 47 (20): 11849-11857. DOI: 10.1021/es402165b

VAN WEERT, F., J. VAN DER GUN \& J.
RECKMAN. 2009. Global overview of saline groundwater occurrence and genesis. Utrech, The Netherlands. Available at: https://www. un-igrac.org/file/182/download?token=s8rzZzJj

WILLIAMS, D. D. \& B. W. FELTMATE. 1992. Aquatic insects. Cab International. Wallingford, Oxon, UK.

WILLIAMS, W. D. 1987. Salinization of rivers and streams: an important environmental hazard. $A M B I O, 16$ (4): 180-185.

WILLIAMS, W. D. 2001a. Anthropogenic salinisation of inland waters. Hydrobiologia, 466 (1): 329-337. DOI: 10.1023/A:1014598509028

WILLIAMS, W. D. 2001b. Salinization: unplumbed salt in a parched landscape. Water Science and Technology, 43 (4): 85-91. DOI: 10.2166/wst.2001.0186

WILLIAMS, W. D., A. J. BOULTON \& R. G. TAAFFE. 1990. Salinity as a determinant of salt lake fauna: a question of scale. Hydrobiologia, 197: 257-266. DOI: 10.1007/BF00026955

WILSON, S. M. 2004. Dryland and urban salinity costs across the Murray-Darling Basin. An overview \& guidelines for identifying and valuing the impacts. Murray-Darling Basin Commission, Canberra, Australia. Available at: https:/www.mdba.gov.au/sites/default/files/ archived/mdbc-salinity-reports/2070 Dryland and urban_salinity_costs_across_MDB.pdf

ZUIDEMA, S., W. M. WOLLHEIM, M. M. MINEAU, M. B. GREEN \& R. J. STEWART. 2018. Controls of Chloride Loading and Impairment at the River Network Scale in New England. Journal of Environmental Quality, 47: 839-847. DOI: $10.2134 /$ jeq2017.11.0418 